In cooperation with the Miami Conservancy District

\title{
Evaluation of Nitrate Concentrations and Sources in the Elk Creek Watershed, Southwestern Ohio, 2003-2004
}

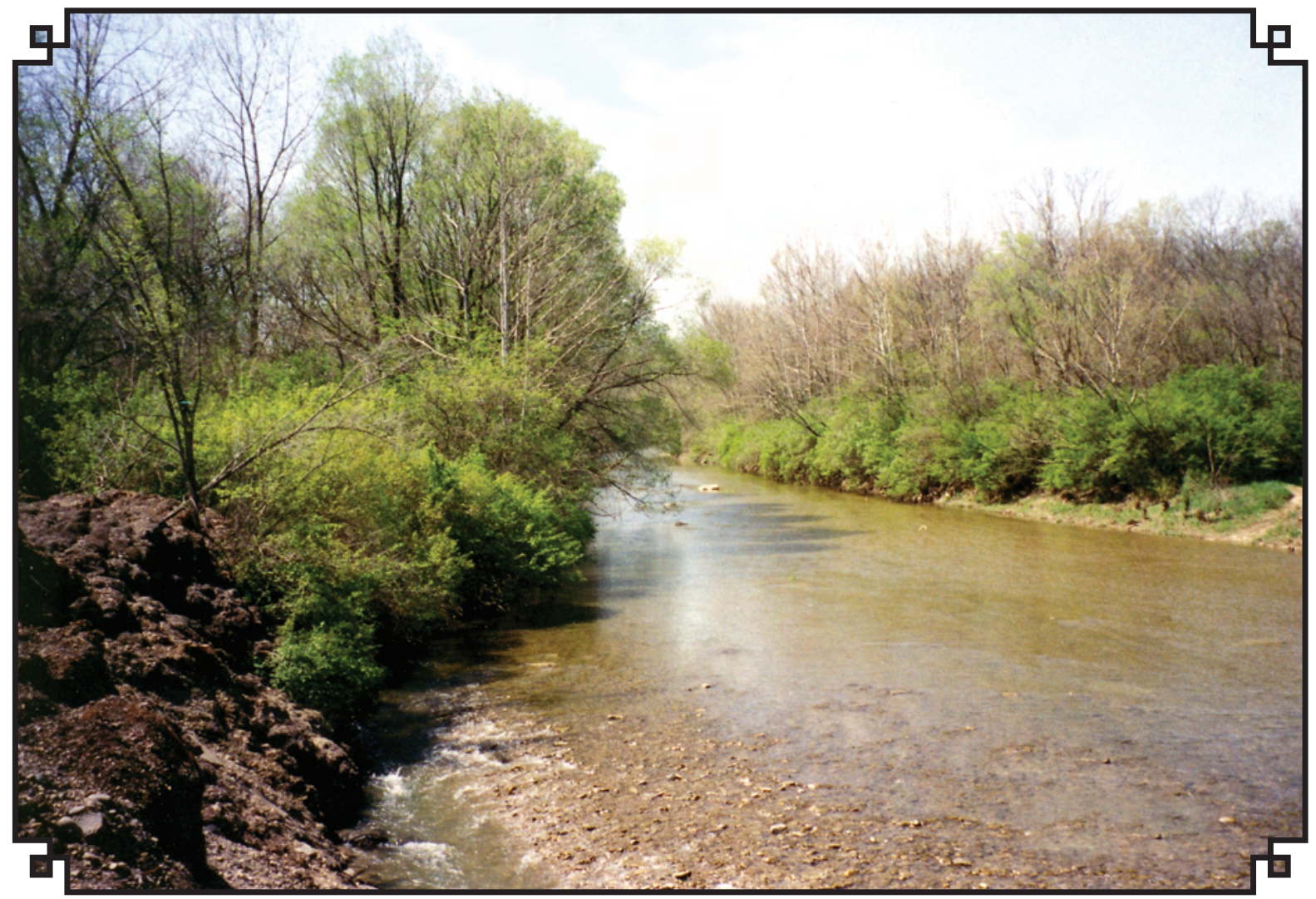

Scientific Investigations Report 2006-5223 
COVER PHOTOGRAPH: Elk Creek, looking north, near Trenton, Ohio. (Photo by Tom Schumann, U.S. Geological Survey) 


\section{Evaluation of Nitrate Concentrations and Sources in the Elk Creek Watershed, Southwestern Ohio, 2003-2004}

By Thomas L. Schumann and Bruce A. Pletsch

In cooperation with the Miami Conservancy District

Scientific Investigations Report 2006-5223 


\title{
U.S. Department of the Interior \\ DIRK KEMPTHORNE, Secretary
}

\author{
U.S. Geological Survey \\ Mark D. Myers, Director
}

U.S. Geological Survey, Reston, Virginia: 2006

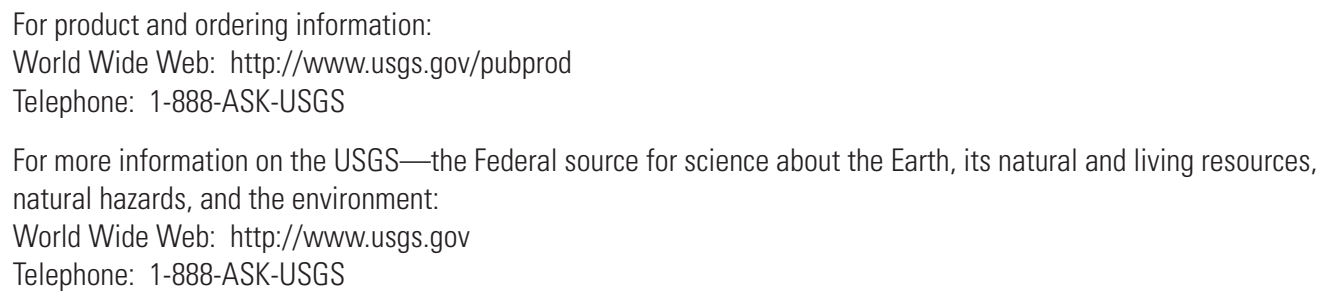

Any use of trade, product, or firm names is for descriptive purposes only and does not imply endorsement by the U.S. Government.

Although this report is in the public domain, permission must be secured from the individual copyright owners to reproduce any copyrighted materials contained within this report.

Suggested citation:

Schumann, T.L., and Pletsch, B.A., 2006, Evaluation of nitrate concentrations and sources in the Elk Creek watershed, southwestern Ohio, 2003-2004: U.S. Geological Survey Scientific Investigations Report 2006-5223, 30 p. 


\section{Contents}

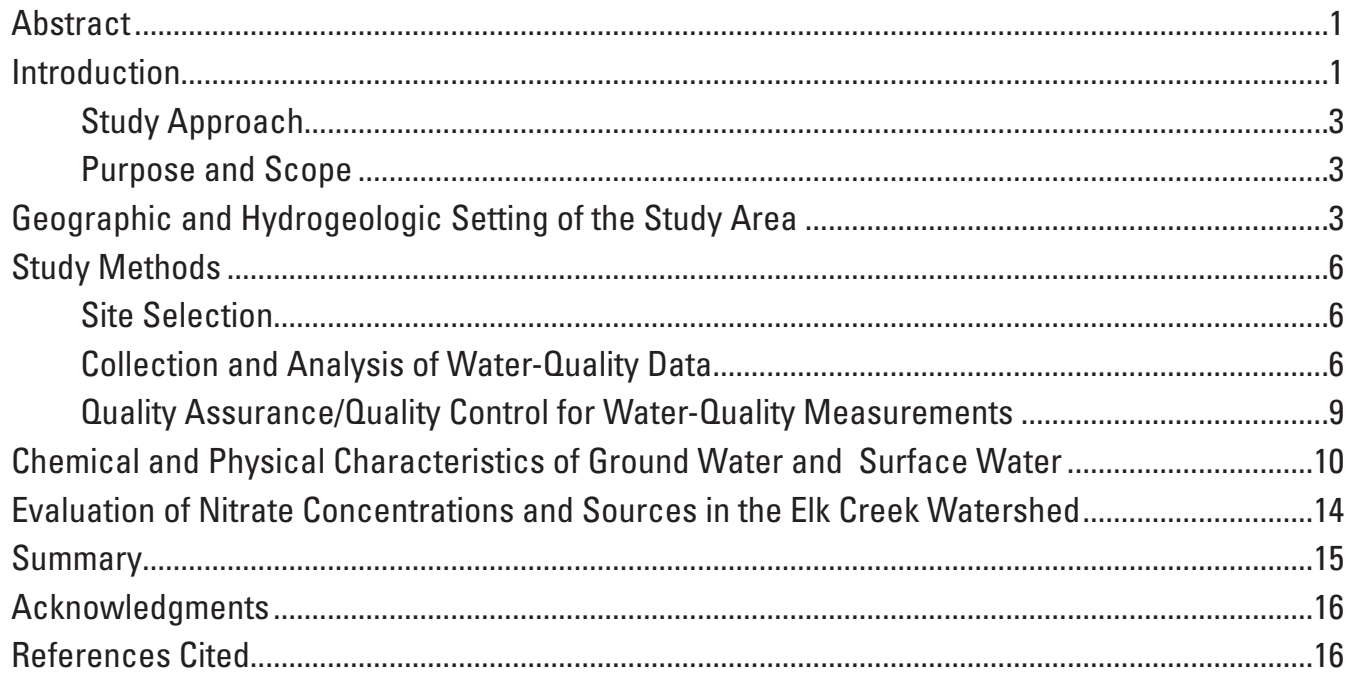

\section{Figures}

1.-6. Maps showing:

1. Location of the Elk Creek watershed (study area), southwestern Ohio................................2

2. Ground-water and surface-water sampling locations in the Elk Creek watershed ..............4

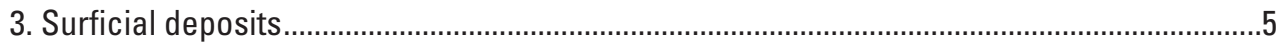

4. Land use, 1994 ……...................................................................................................

5. Potentiometric surface of water in surficial deposits........................................................

6. Nitrate concentrations in ground and surface water .......................................................11

7. Graph showing nitrogen and oxygen isotope ratios of nitrate in ground water and

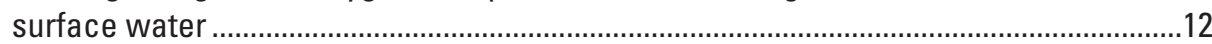

8. Trilinear diagram showing percentages of major ions in ground-water samples from unconsolidated deposits from four wells .13

\section{Tables}

1. Water-quality characteristics of water samples collected from sites in the

Elk Creek watershed, southwestern Ohio, September 2003 through October 2004 ........19

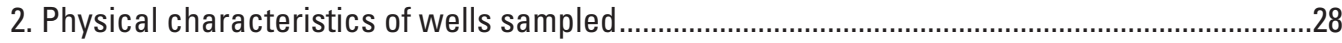

3. Streamflow measurements at surface-water sites ................................................................30 


\section{Conversion Factors, Definitions, and Datum}

\begin{tabular}{|c|c|c|}
\hline Multiply & By & To obtain \\
\hline \multicolumn{3}{|c|}{ Length } \\
\hline foot $(\mathrm{ft})$ & 0.3048 & meter $(\mathrm{m})$ \\
\hline mile (mi) & 1.609 & kilometer $(\mathrm{km})$ \\
\hline \multicolumn{3}{|c|}{ Area } \\
\hline square mile $\left(\mathrm{mi}^{2}\right)$ & 2.590 & square kilometer $\left(\mathrm{km}^{2}\right)$ \\
\hline \multicolumn{3}{|c|}{ Volume } \\
\hline gallon (gal) & 3.785 & liter $(\mathrm{L})$ \\
\hline \multicolumn{3}{|c|}{ Flow rate } \\
\hline gallon per minute (gal/min) & 0.06309 & liter per second (L/s) \\
\hline gallon per minute (gal/min) & 3.785 & liter per minute (L/min) \\
\hline million gallons per day (Mgal/d) & 0.04381 & cubic meter per second $\left(\mathrm{m}^{3} / \mathrm{s}\right)$ \\
\hline \multicolumn{3}{|c|}{ Hydraulic gradient } \\
\hline foot per mile (ft/mi) & 0.1894 & meter per kilometer $(\mathrm{m} / \mathrm{km})$ \\
\hline
\end{tabular}

Temperature in degrees Celsius $\left({ }^{\circ} \mathrm{C}\right)$ may be converted to degrees Fahrenheit $\left({ }^{\circ} \mathrm{F}\right)$ as follows:

$$
{ }^{\circ} \mathrm{F}=\left(1.8 \mathrm{x}^{\circ} \mathrm{C}\right)+32 .
$$

Abbreviated water-quality units used in this report: Chemical concentrations and water temperature are given in metric units. Chemical concentration is given in milligrams per liter ( $\mathrm{mg} / \mathrm{L}$ ) or micrograms per liter $(\mu \mathrm{g} / \mathrm{L})$. Milligrams per liter is a unit expressing the concentration of chemical constituents in solution as weight (milligrams) of solute per unit volume (liter) of water. One thousand micrograms per liter is equivalent to one milligram per liter. For concentrations less than 7,000 $\mathrm{mg} / \mathrm{L}$, the numerical value is approximately the same as for concentrations in parts per million.

Bacteria concentrations are given in colonies per 100 milliliters (col/100 mL).

Specific conductance of water is expressed in microsiemens per centimeter at 25 degrees Celsius $(\mu \mathrm{S} / \mathrm{cm})$. This unit is equivalent to micromhos per centimeter at 25 degrees Celsius $(\mu \mathrm{mho} / \mathrm{cm})$ formerly used by the U.S. Geological Survey.

Stable isotope ratios are indicated by use of the delta symbol $(\delta)$ coupled with the atomic mass and chemical symbol, such as $\delta^{15} \mathrm{~N}$, and are expressed in parts per thousand (per mil) relative to a standard. The isotope itself is simply expressed as ${ }^{15} \mathrm{~N}$.

Turbidity is expressed in nephelometric turbidity units, abbreviated as NTU.

Filter pore size for inorganic constituents is 0.45 micrometers $(\mu \mathrm{m})$. One micrometer is equivalent to 0.001 millimeter.

Vertical coordinate information is referenced to the National Geodetic Vertical Datum of 1929 (NGVD 29).

Altitude, as used in this report, refers to distance above the vertical datum.

Horizontal coordinate information is referenced to the North American Datum of 1927 (NAD 27). 


\title{
Evaluation of Nitrate Concentrations and Sources in the Elk Creek Watershed, Southwestern Ohio, 2003-2004
}

\author{
By Thomas L. Schumann and Bruce A. Pletsch ${ }^{1}$
}

\section{Abstract}

Nitrate concentrations exceeding the U.S. Environmental Protection Agency maximum contaminant level of 10 milligrams per liter have been reported in ground water near the City of Trenton, Ohio, in the southern part of the Elk Creek watershed. A study of nitrate concentrations and sources in surface and ground water within the Elk Creek watershed was conducted during 2003 and 2004.

Nitrate concentrations in the Elk Creek watershed range from less than 0.06 to 11 milligrams per liter. The likely sources of elevated nitrate in the ground water near the City of Trenton appear to be soil organic matter and ammonia fertilizer. Land use is predominantly (93 percent) agricultural, with no identified point sources of nitrate. Likely sources of nitrate in the surface water appear to be manure and septic system effluent, soil organic matter, and ammonia fertilizer.

Water-quality constituents, including nitrate, were sampled in water from 38 wells and at 6 surface-water sites. The wells were all shallow (less than 105 feet deep), with open intervals in aquifers of glacial origin, that include tills, outwash, and alluvium. Nitrate concentrations (median of 0.06 milligrams per liter) in the ground water of the upper section of the watershed were lower than those in the lower section of the watershed (median of 4.2 milligrams per liter).

Nitrate was analyzed for nitrogen and oxygen isotope values. The $\delta^{15} \mathrm{~N}$ and $\delta^{18} \mathrm{O}$ range from -22.36 to +32.29 per mil, and -6.27 to +17.72 per mil, respectively. A positive correlation of $\delta^{15} \mathrm{~N}$ and $\delta^{18} \mathrm{O}$ enrichment indicates that denitrification is a prevalent process within the watershed.

\section{Introduction}

Elevated levels of nitrogen-based nutrients such as nitrate can contribute to degradation of surface-water bodies through eutrophication and eventually can create hypoxia, such as that found periodically in the Gulf of Mexico (Battaglin and others, 2001). Nitrate concentrations greater than $10 \mathrm{mg} / \mathrm{L}$ in drinking

${ }^{1}$ Miami Conservancy District water from surface- and ground-water sources is a public-health concern. Nitrate ingested at high concentrations can interfere with the oxygen-carrying capacity of blood in infants (a condition called methemoglobinemia) and may contribute to the formation of carcinogenic nitrosamine compounds in humans (Shearer and others, 1972). Consequently, the U.S. Environmental Protection Agency (USEPA) regulates public-water suppliers for nitrate and has established a maximum contaminant level (MCL) of $10 \mathrm{mg} / \mathrm{L}$ (U.S. Environmental Protection Agency, 2003). Nitrate concentrations have exceeded this MCL in some public-water supplies in the U.S., largely because of overuse of fertilizers and contamination by human and animal waste.

Many residents throughout the Elk Creek watershed in southwestern Ohio depend on ground water as a drinking-water source. The City of Trenton, Ohio, withdraws water from a buried-valley aquifer underlying the southeastern part of the Elk Creek watershed (fig. 1). The city sampled ground water from a potential public-water-supply well completed in a sand and gravel aquifer for several years prior to bringing the well into service in 2006. Nitrate concentrations in some of these samples exceeded the MCL of $10 \mathrm{mg} / \mathrm{L}$ (Todd Kehr, City of Trenton, oral commun., 2003). No studies had been conducted to determine if nitrate exceeds the MCL in other parts of the Elk Creek watershed or to identify the source of nitrate in ground water near the City of Trenton. To address these issues, the U.S. Geological Survey (USGS), in cooperation with the Miami Conservancy District, conducted a study to evaluate nitrate concentrations and sources in the Elk Creek watershed during 2003 and 2004.

Land use is predominantly (93 percent) agricultural; 4 percent of the watershed is urban. On the basis of land use in the watershed, possible nonpoint sources for nitrate include commercial ammonia and nitrate fertilizers, manure, naturally occurring soil organic matter, nearby septic effluent, and atmospheric deposition.

Nitrogen isotope ratios can be used to identify potential sources of nitrate in ground water (Komor and Anderson, 1993; Böhlke and Denver, 1995; Kendall, 1998). Different sources of nitrate have characteristic ranges of nitrogen-isotope ratios. Analyses of water samples can be complicated, however, by natural processes such as denitrification, ion exchange, and 


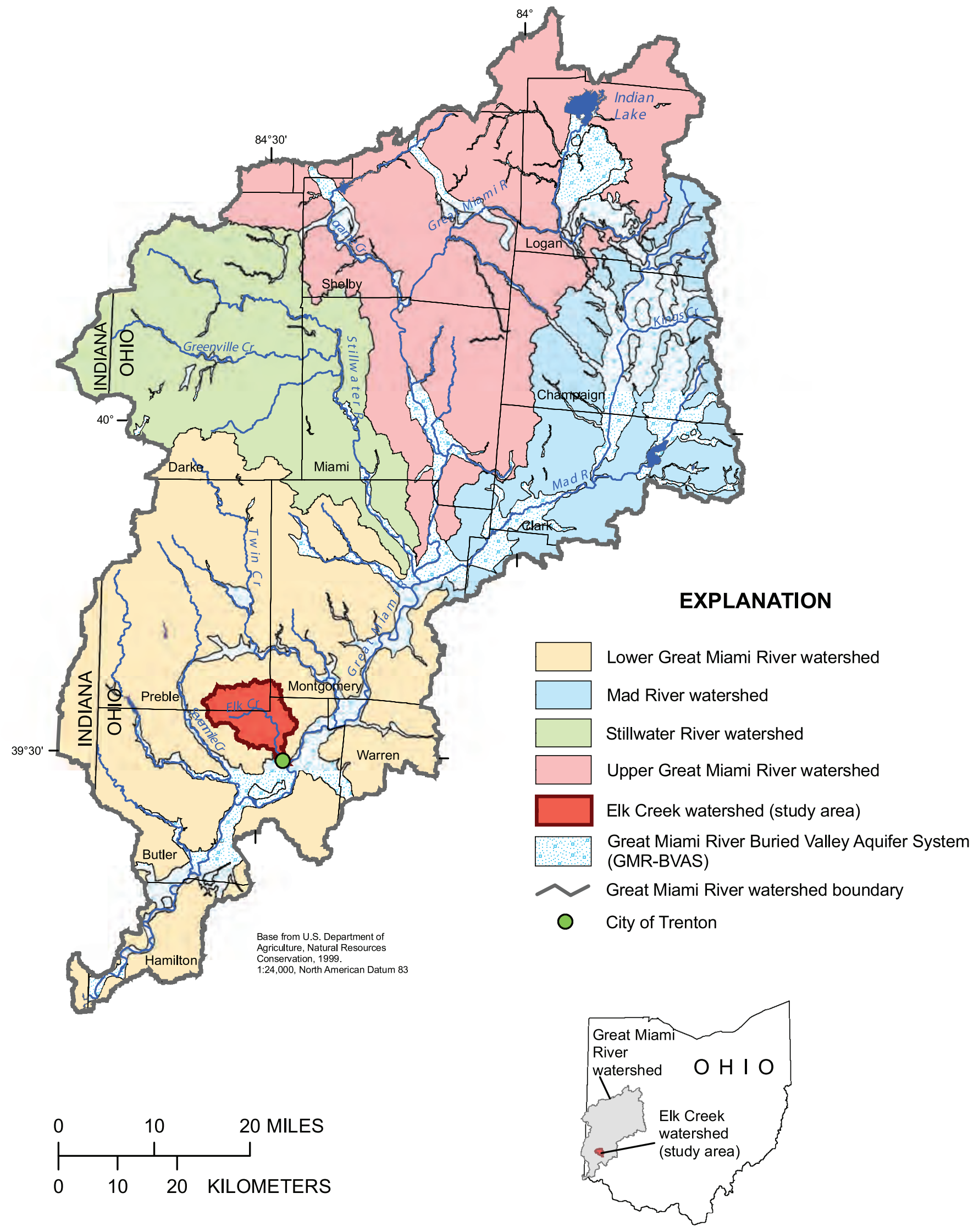

Figure 1. Location of the Elk Creek watershed (study area), southwestern Ohio. 
plant uptake that result in isotopic fractionation. A dual-isotope approach that analyzes ${ }^{18} \mathrm{O}$ in addition to ${ }^{15} \mathrm{~N}$ isotopes of nitrate can provide a clearer determination of nitrate sources than analyzing ${ }^{15} \mathrm{~N}$ alone because many nitrate sources have distinctive combined $\delta^{18} \mathrm{O}$ and $\delta^{15} \mathrm{~N}$ values (Kendall and others, 1995).

\section{Study Approach}

The study was designed to assess the distribution of nitrate in ground and surface water throughout the watershed and used a dual-isotope approach to identify nitrate sources. The fieldwork for this study was divided into two phases. The lower watershed, south of the confluence of Dry Run with Elk Creek, was sampled in phase one. The upper watershed, north of the confluence of Dry Run and Elk Creek, was sampled in phase two (fig. 2). Fieldwork during phase one was conducted September 30 to December 18, 2003, with emphasis on collecting ground-water data north of the City of Trenton. Field work during phase two was conducted August 16 to October 22, 2004, with emphasis on collecting surface- and ground-water data in the remainder of the Elk Creek watershed. Identical methods for all field and laboratory procedures were used during the two phases.

Ground-water samples were collected from 38 shallow wells (less than 105 feet deep) screened in glacial aquifers within the Elk Creek watershed. Six surface-water samples were collected, and discharge measurements were made at intervals along the 12.6-mi reach of Elk Creek from the northwestern part of the watershed to near the confluence of Elk Creek with the Great Miami River (fig. 2).

All samples were analyzed for nutrients, nitrate, nitrite, ammonia, dissolved organic carbon (DOC), and alkalinity to characterize the ground water and surface water in the watershed. All samples containing nitrate concentrations greater than $0.06 \mathrm{mg} / \mathrm{L}$ subsequently were analyzed for the stable isotopes of nitrate (for nitrogen, ${ }^{15} \mathrm{~N}$ and ${ }^{14} \mathrm{~N}$; and for oxygen, ${ }^{18} \mathrm{O}$ and ${ }^{16} \mathrm{O}$ ) to identify the sources of the nitrate. Samples from four sites representing the glacial-aquifer mineralogy and geochemistry were analyzed for major ions to assess the general ground-water characteristics in the watershed.

\section{Purpose and Scope}

This report (1) assesses the prevalence of elevated concentrations of nitrate throughout the Elk Creek watershed, (2) evaluates any spatial variation that may exist regarding nitrate concentrations within the watershed, and (3) identifies the likely sources of nitrate within the watershed. This report also documents methods used throughout the project and data collected from August through October 2004. Data collected during phase one, from September through December 2003, were presented in a previous report (Pletsch and Schumann, 2004); for a comprehensive analysis, those data are reproduced here and included with the 2004 phase two data. Analyses and results are based on all historical data and data collected during the 2003 and 2004 sampling phases.

\section{Geographic and Hydrogeologic Setting of the Study Area}

Elk Creek is in the south-central part of the Great Miami River watershed (fig. 1). The geology of the Great Miami River watershed consists of unconsolidated Pleistocene glacial deposits, predominantly Wisconsinan and Illinoian in age, overlying a thick sequence of older limestones and shales of Devonian, Silurian, and Ordovician age (Klaer and Thompson, 1948; Norris and Spieker, 1966). The geology of the region influences many of the physical properties of the landscape such as soil type, topography, runoff, and the quality of surface and ground water. The types of surficial deposits in a watershed and their distribution are important in determining how water is transported through the system and the amount and types of dissolved minerals in the water (Debrewer and others, 2000).

The Great Miami River channel is 170.3 mi long, with a watershed that drains an area of approximately 5,385 $\mathrm{mi}^{2}$. The watershed has a length of approximately $120 \mathrm{mi}$ and contains parts of 15 counties in Ohio and 2 in Indiana (fig. 1). Landsurface altitudes range from $1,550 \mathrm{ft}$ in the northern parts of the watershed to $450 \mathrm{ft}$ at the confluence of the Great Miami River with the Ohio River in Hamilton County, Ohio (Miami Conservancy District, 2002).

Major aquifer systems within the Great Miami River watershed include sand and gravel buried- valley aquifers associated with the Great Miami River and its principal tributaries, shale and limestone bedrock aquifers, and water-bearing sand and gravel lenses within overlying glacial till. Of these major aquifer systems, the Great Miami River Buried Valley Aquifer System (GMR-BVAS) is the most-productive ground-water resource (Ohio Department of Natural Resources, 1999). This large aquifer system (fig. 1) provides potable water for many communities within the Great Miami River Watershed (Miami Conservancy District, 2001; Miami Conservancy District, 2002). The GMRBVAS consists of highly permeable sand and gravel deposits that fill or partially fill preglacial river valleys.

The study area, the Elk Creek watershed, is $47.7 \mathrm{mi}^{2}$ (Ohio Department of Natural Resources, 1967) and includes parts of Butler, Preble, and Montgomery counties (fig. 1). The entire study area is within the Southern Ohio Loamy Till Plain section (Brockman, 1998) of the Central Lowland Physiographic Province (Fenneman, 1938) and overlies a part of the GMR-BVAS. Land use within the watershed is approximately 93 percent agricultural, 3 percent forest, and 4 percent urban developed for commercial and residential use (Ohio Department of Natural Resources, 1994). The largest urban area in the watershed is the northeastern part of the City of Trenton, population 8,746 (U.S. Census Bureau, 2000), in the southeastern tip of the watershed. This urban area, which includes the City of Trenton's Northeast Wellfield (fig. 2 inset), is developing rapidly and was 


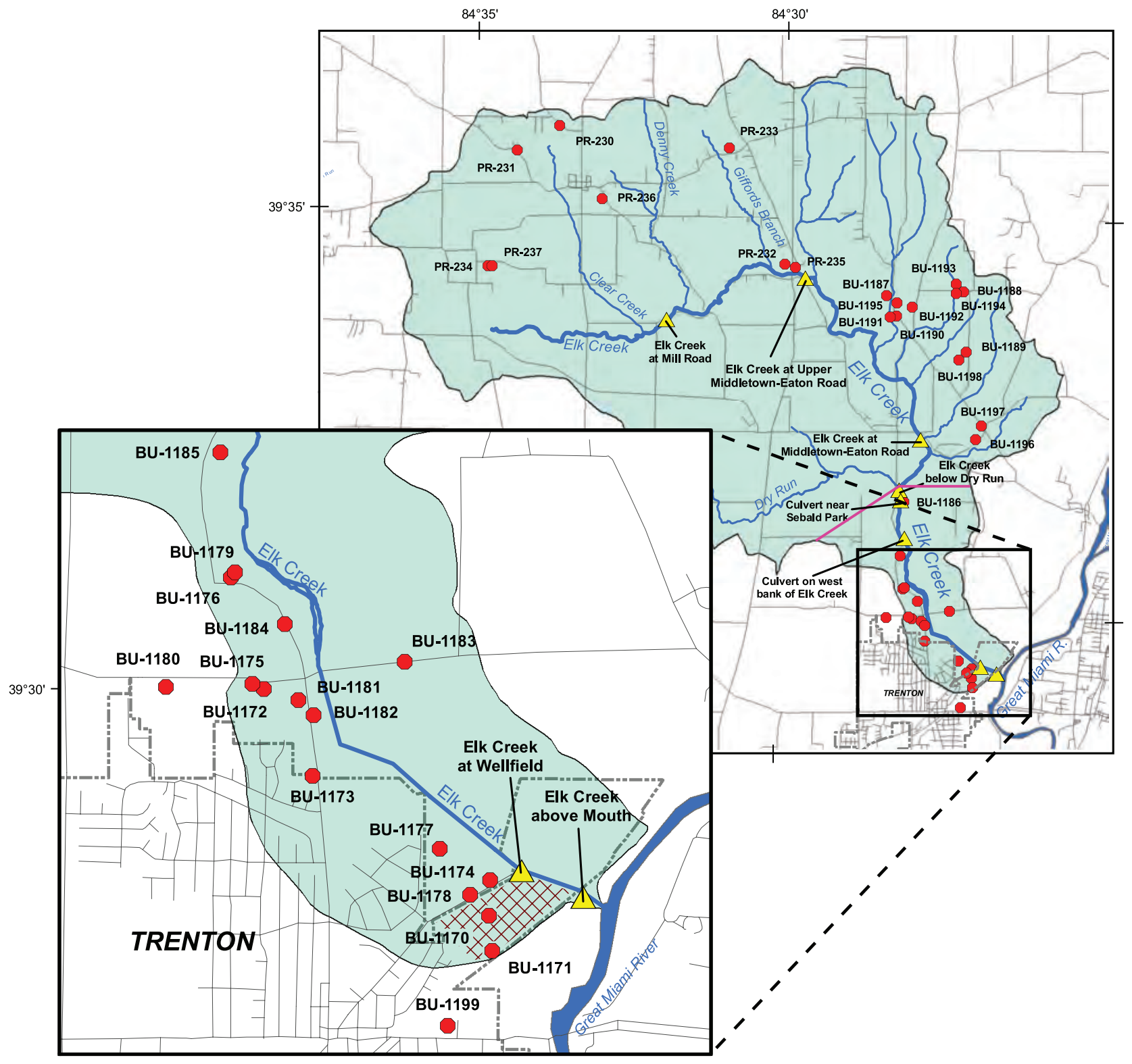
Base from U.S. Department of
Agriculture, Natural Resources

1:24,000, North American Datum 83

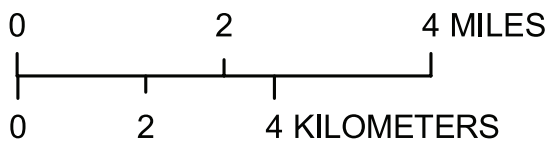

\section{EXPLANATION}

Elk Creek watershed

Trenton Northeast Wellfield

Trenton corporate boundary

Upper/lower watershed divide

BU-1170 Well location and station name Elk Creek above Mouth Surface-water site location

Figure 2. Ground-water and surface-water sampling locations in the Elk Creek watershed, southwestern Ohio. 


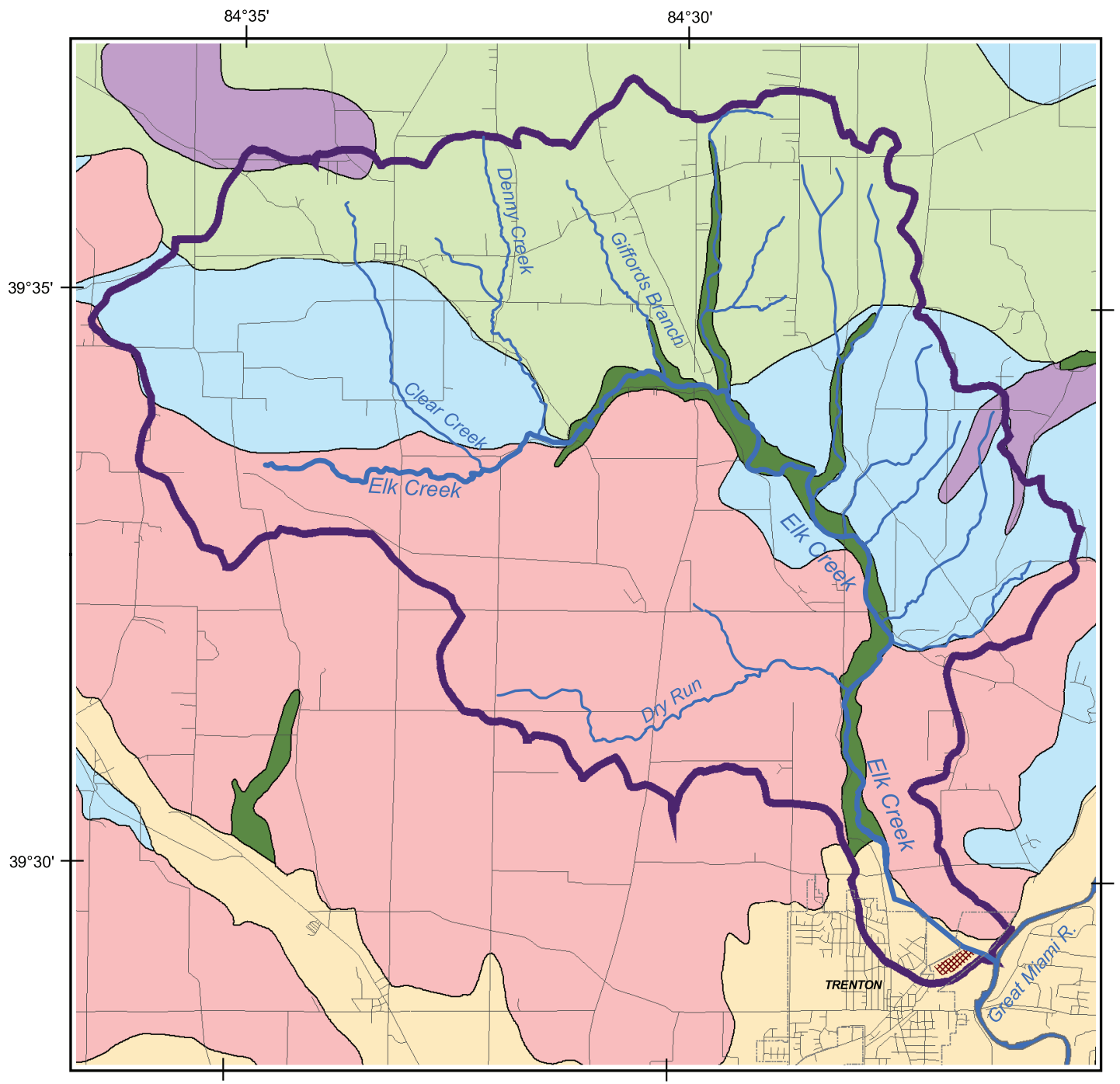

Unconsolidated aquifers from Ohio Department of Natural Resources, Division of Water, 2000.

\section{EXPLANATION}

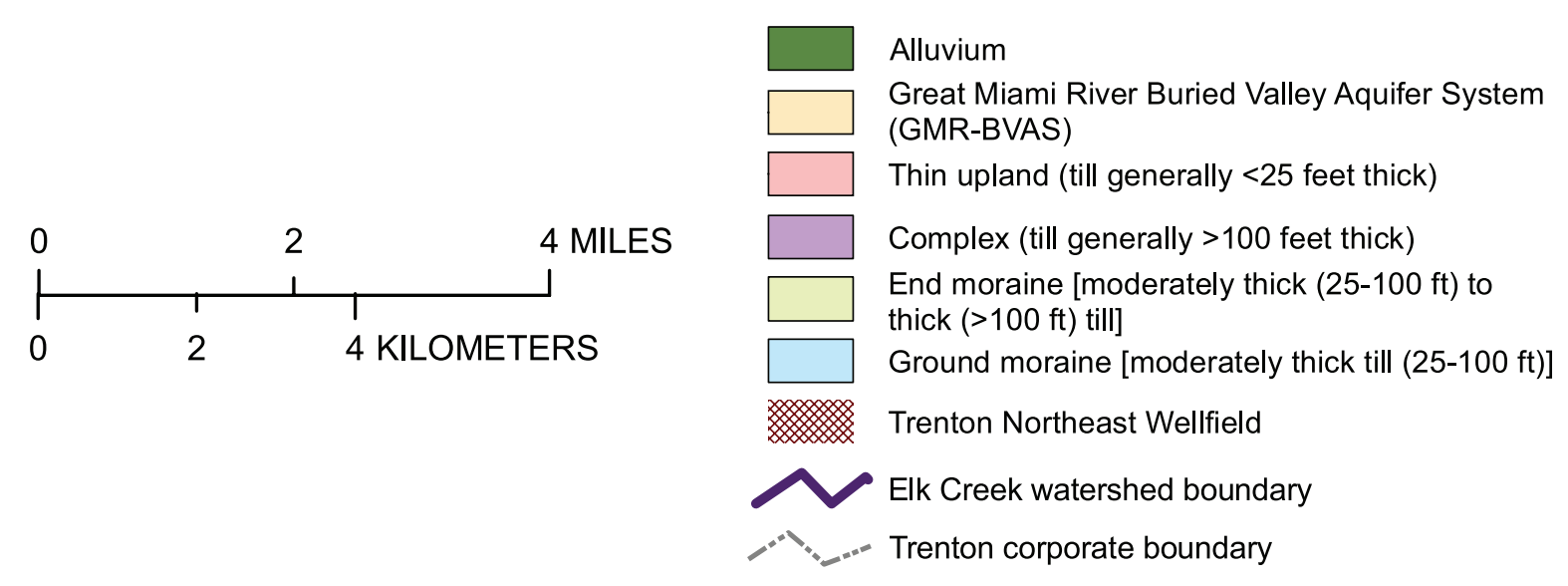

Figure 3. Surficial deposits in the Elk Creek watershed, southwestern Ohio. 
an agricultural as recently as September 1999 (Todd Kehr, oral commun., 2003). The GMR-BVAS (fig. 3) is the primary source of local potable water in this urban area.

Surficial deposits in the Elk Creek watershed consist primarily of Holocene alluvial and Pleistocene till and glacial outwash deposits (fig. 3). The modern alluvial deposits are along Elk Creek and consist of silty sand, gravel, and clayey till. Low water yields of 3 to $10 \mathrm{gal} / \mathrm{min}$ have been reported from wells completed in interbedded layers of sand and gravel at depths greater than $25 \mathrm{ft}$ (Schmidt, 1986). Some wells in this study, such as BU-1195 and BU-1186, are completed in alluvial deposits and have yields of 35 and $50 \mathrm{gal} / \mathrm{min}$, respectively.

Glacial deposits in the Elk Creek watershed include buried valleys (GMR-BVAS) and till mapped as four distinct deposits in figure 3: thin upland, complex, end moraine, and ground moraine. The GMR-BVAS near the City of Trenton consists of highly permeable sand and gravel layers deposited by glacial meltwaters during several glacial events in southwestern Ohio. Recharge to the sand and gravel aquifer includes infiltration of precipitation, inflow of ground water from adjacent uplands, infiltration of river water from reaches where surface-water recharge occurs (Norris and Spieker, 1966), and possibly induced infiltration near pumping wells (Sheets and others, 2002). Water yields from wells completed in the GMR-BVAS range from 100 to more than 1,000 gal/min (Schmidt, 1986).

Well yields less than $2 \mathrm{gal} / \mathrm{min}$ are typical from the thin upland glacial deposits in the southern part of the watershed (Schmidt, 1986). The thickness of these deposits is generally less than $35 \mathrm{ft}$. The thin upland glacial deposits comprise clayey till with sand and gravel lenses that overlie shaley limestone.

Complex till deposits are generally more than $100 \mathrm{ft}$ thick. These deposits are till that is not defined as either upland or moraine; the till consists of clay and silt with interbedded sand and gravel layers. Complex till is found in two small areas within the Elk Creek watershed (fig. 3).

Glacial moraine deposits include end and ground moraines that are north and east of Elk Creek. Moderate yields (5 to $25 \mathrm{gal} / \mathrm{min}$ ) can be obtained from sand and gravel layers interbedded with the thick layers of clay in these moraines (Walker, 1986). The moraine deposits may be 160 to $230 \mathrm{ft}$ thick, but the water-bearing units within them are generally thin and not extensive (Schmidt, 1986).

In 2003, the Miami Conservancy District completed a regional synoptic water-level survey in eastern Butler County, Ohio, which included the City of Trenton. Based on this survey, the regional ground-water-flow direction is from the northeast to the southwest (Michael Ekberg, Miami Conservancy District, oral commun., 2003). Water levels collected from 38 wells during 2003 and 2004 (table 2) indicate that ground-water flow in the surficial deposits of the Elk Creek watershed follows topographic contours and generally moves toward Elk Creek (fig. 5).
Ground-water-flow paths in the upper watershed in the glacial and alluvial sediments follow surface topography, and flow is toward Elk Creek (fig. 5). The ground-water-flow paths in the southwestern section of the lower watershed are also predominantly toward Elk Creek, with the exception of the area near the Northeast Wellfield. Because of high permeability of the aquifer material, water pumped by the production wells may be coming from Elk Creek by way of induced infiltration, local ground water along preferred flow paths, the GMR-BVAS near the Great Miami River, or possibly outside the study area.

\section{Study Methods}

All water samples were collected by USGS or Miami Conservancy District personnel. Standard USGS water-quality sampling and analytical methods as detailed by Wilde and others $(1999,2004)$ were used in sampling all wells. Site location, elevation, and field identification were determined by global positioning system instrumentation or topographic maps. Photographs of each site for future reference were taken and stored at the USGS Ohio Water Science Center in Columbus.

\section{Site Selection}

Selection of ground-water sites focused on wells completed in unconsolidated glacial and alluvial aquifers that were either within or adjacent to the Elk Creek watershed. Wells in the southeastern tip of the Elk Creek watershed, near the City of Trenton, were inventoried during the first phase of the study (2003). Wells throughout the remainder of the watershed were inventoried during the second phase of the study (2004). Study sites were selected from these lists. Representative spatial distribution, availability and evaluation of well logs, and access to property were other site-selection criteria.

\section{Collection and Analysis of Water-Quality Data}

Ground-water samples were collected from 20 domestic wells during 2004. Ground-water samples were collected from 14 domestic, 1 industrial, and 3 public-supply wells during 2003. All samples were collected directly from the well owners' dedicated spigot, using the existing well-pump system. Samples were collected at all sites prior to any water treatment, such as water softeners. USGS personnel inspected all of the systems that were sampled.

All ground-water samples were collected after field personnel determined wells were purged of at least three casing volumes of water and verified that onsite measurements of $\mathrm{pH}$, temperature, dissolved oxygen (DO), specific conductance, and turbidity had stabilized. Onsite measurements were made at all sites, using a field-calibrated multiparameter probe. Onsite measurements were considered stable when five 


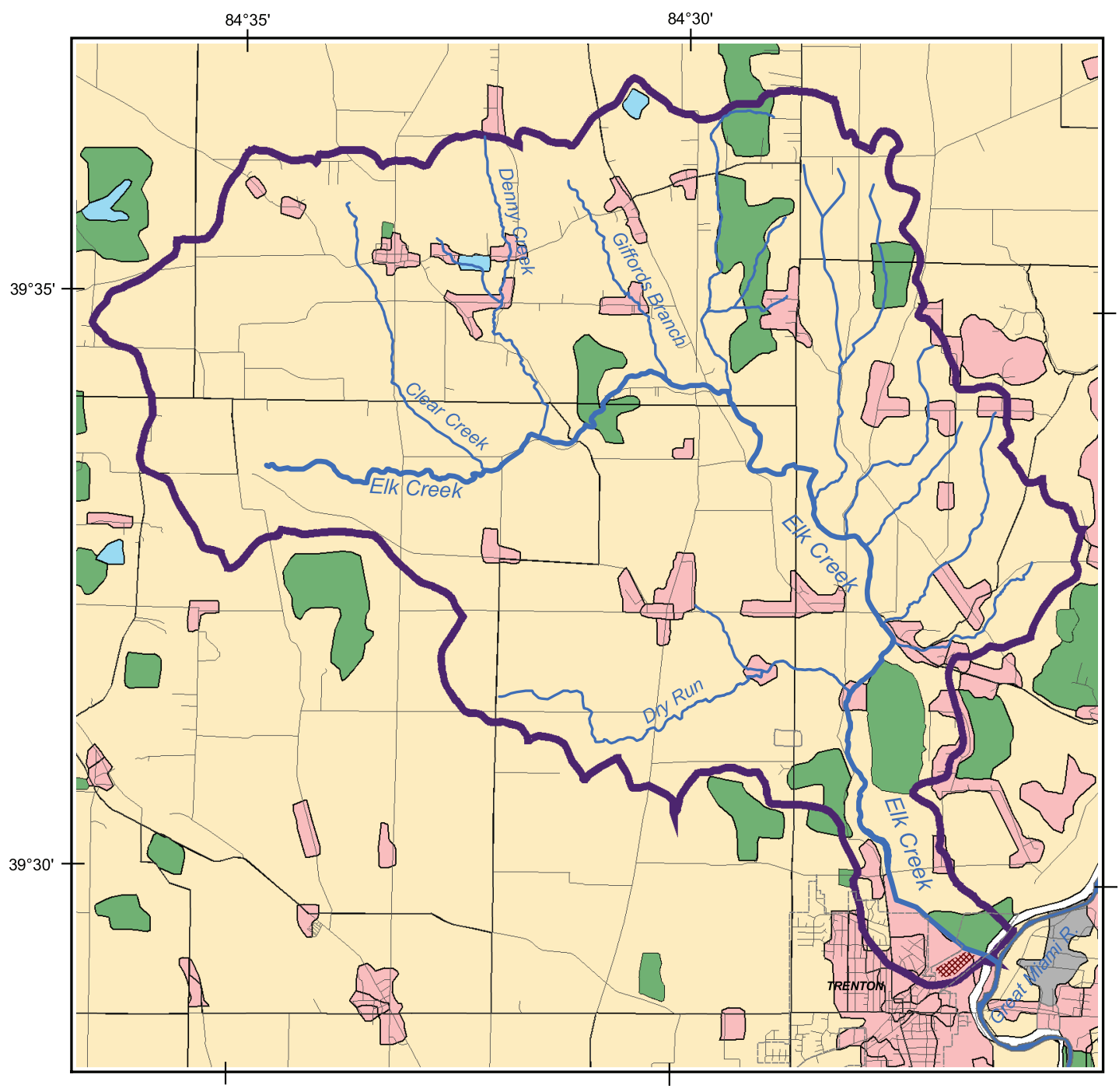

Land use/land cover from Ohio

Department of Natural Resour

North American Datum 27, South Zone (3402)

EXPLANATION

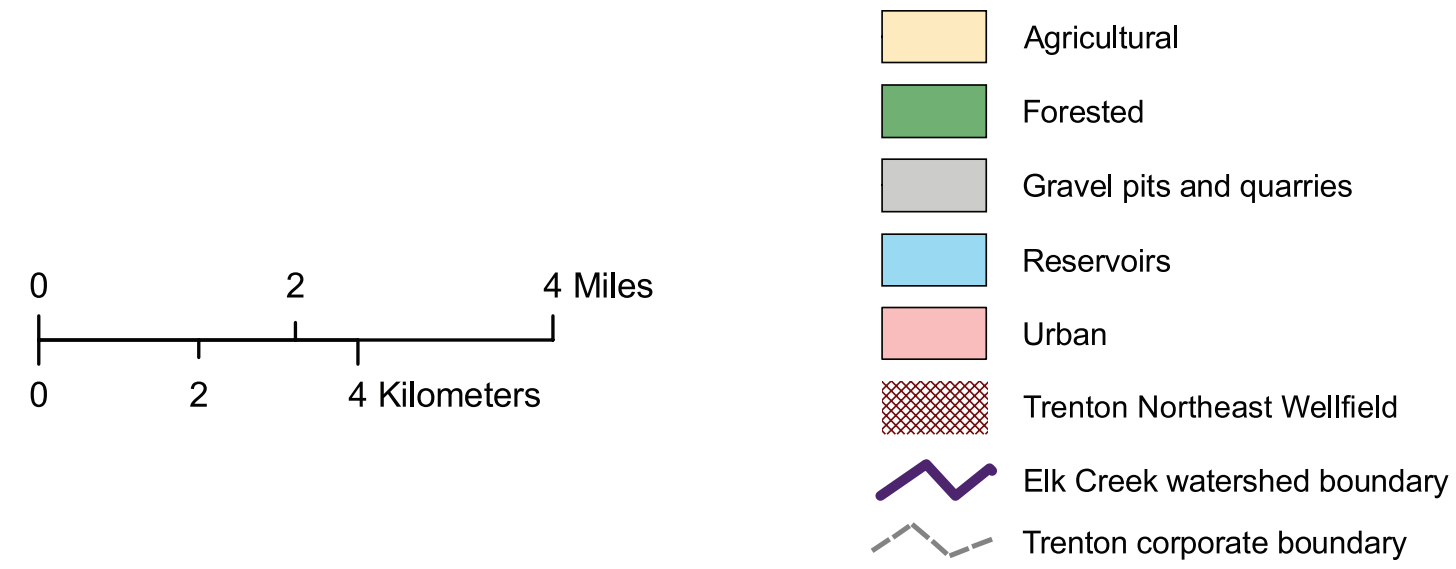

Figure 4. Land use in the Elk Creek watershed, southwestern Ohio, 1994. 


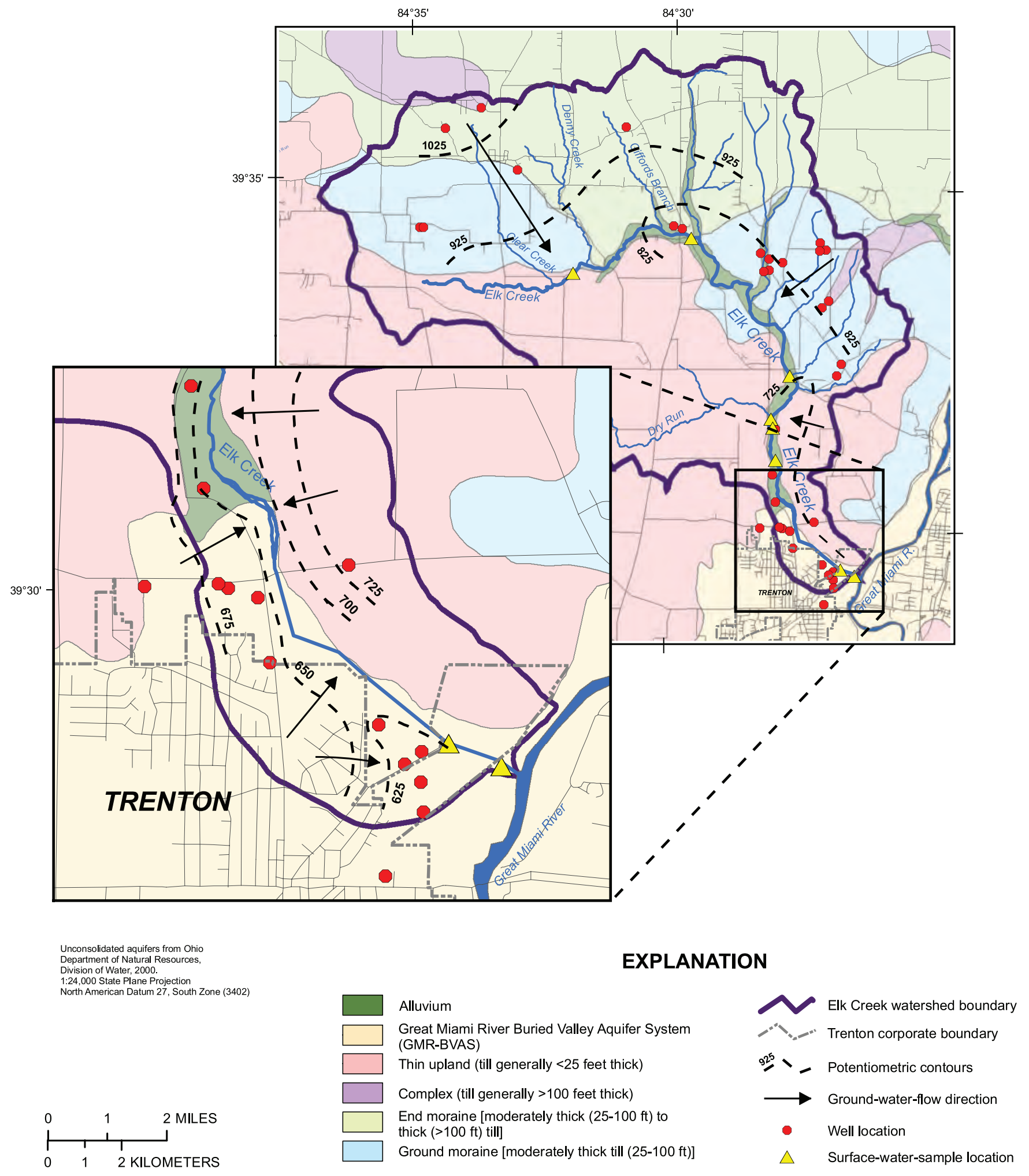

Figure 5. Potentiometric surface of water in surficial deposits in the Elk Creek watershed, southwestern Ohio. 
sequential readings taken at 1-minute intervals were within accepted ranges of variation. Water was passed through a $0.45-\mu \mathrm{m}$ capsule filter for nutrient, isotope, DOC, and alkalinity analyses. All samples were preserved by chilling on ice and (or) by acidification following USGS protocol (Wilde and others, 2004).

Samples were collected from six surface-water sites along Elk Creek during August 2004. Five of the sites were downstream from major tributaries, and one site was upstream from the confluence with the Great Miami River. The six surface-water sites were sampled during low-flow conditions to achieve the best representation of ground-water influence. During this low-flow period, streamflow in Elk Creek was almost exclusively from base flow or ground-water inflow. Under other hydrologic conditions, direct precipitation, surface runoff, interflow, and baseflow contribute to surfacewater flow. Low-flow conditions were determined, using the discharge measurement in Elk Creek and streamflow studies by Straub (2001). Streamflow in Elk Creek below Dry Run on August 16, 2004 was $1.74 \mathrm{ft} \mathrm{ft}^{3} / \mathrm{s}$; streamflow was considered low flow because it was exceeded 85 percent of the time during an average climatic year based on a period of record of April to March, as calculated with the duration-of-flow analysis method.

Samples were collected, using the equal-width-increment (EWI) method that produces a representative mixture of surface-water flow. The EWI method is the collecting and compositing of depth-integrated subsamples taken at equal distances across the entire stream width (Wilde and others, 1999). Streamflow was measured at each of the six surface-water sites at the time of sampling using standard USGS methods. Most tributaries to Elk Creek between the farthest upstream site and the mouth of Elk Creek were dry, wet but not flowing, or flowing at a rate too low to be measured by a pygmy current meter or other mechanical means. Two culvert outfalls to Elk Creek downstream from Dry Run contained measurable discharge; water-quality samples were not collected from these two sites.

The USGS National Water Quality Laboratory in Denver, Colo., analyzed samples for dissolved nutrients, nitrate, nitrite, ammonia, major ion concentrations, and DOC. The USGS Reston Stable Isotope Laboratory in Reston, Va., analyzed nitrogen and oxygen isotope ratios in nitrate from 27 samples that had reported nitrate concentrations greater than $0.06 \mathrm{mg} / \mathrm{L}$ out of 44 total samples, and from BU-1183 that had an estimated nitrate concentration of $0.04 \mathrm{mg} / \mathrm{L}$. Nitrate samples were converted by bacterial reactions to nitrous oxide and subsequently analyzed, using a continuous-flow isotope ratio mass spectrometer to determine the stable isotope ratios. These analyses are expressed, using $\delta$ notation, in units of per mil, defined as:

$$
\delta^{15} \mathrm{~N} \text { or } \delta^{18} \mathrm{O}=\left[\left(\mathrm{R}_{\text {sample }} / \mathrm{R}_{\text {standard }}\right)-1\right] \times 1,000,
$$

where $R$ is the ${ }^{15} \mathrm{~N} /{ }^{14} \mathrm{~N}$ or ${ }^{18} \mathrm{O} /{ }^{16} \mathrm{O}$ ratio for the sample or standard. Nitrogen isotope ratios are reported in parts per thousand (per mil) relative to free nitrogen $\left(\mathrm{N}_{2}\right)$ in air (Mariotti,
1983). Oxygen isotope ratios are reported in per mil relative to Vienna Standard Mean Ocean Water (VSMOW) reference water and normalized on a scale where Standard Light Antarctic Precipitation (SLAP) reference water is -55.5 per mil (Coplen, 1988; 1994). Sample value reproducibility including processing and analysis had a 2 -sigma uncertainty (95 percent repeatability) of 0.5 per mil for nitrogen and 1.0 per mil for oxygen.

The USGS Ohio Water Microbiology Laboratory in Columbus, analyzed total coliform and Escherichia coli (E. coli) bacteria in samples from each ground-water site, using the mI agar method (U.S. Environmental Protection Agency, 2000). Bacterial analyses were conducted to assess likely sources of $\mathrm{NO}_{3}$ such as animal waste or surface contamination of wells. Measured values were reported in terms of the number of bacteria colonies detected per $100 \mathrm{~mL}$ of sample.

\section{Quality Assurance/Quality Control for Water- Quality Measurements}

Data-collection and analytical procedures used in this study incorporated practices designed to control, verify, and assess the quality of sample data. All measurements and samples were collected consistently; the same equipment, sampling personnel, and field vehicle were used during this project. Quality-assurance procedures for the collection and field processing of water-quality samples are described by Francy and others, 1998. Standard procedures of the USGS National Water Quality Laboratory for internal sample handling and quality assurance are described by Pritt and Raese, (1995). Standard procedures of the USGS Reston Stable Isotope Laboratory for internal sample handling and quality assurance are described by Coplen, (2006). Standard procedures of the USGS Ohio Water Microbiology Laboratory for internal sample handling and quality assurance are described by Francy and others (1998) and by the American Public Health Association and others (1992).

Replicate samples were obtained in the field to provide data on precision (reproducibility) for samples exposed to all sources of variability. Precision of analytical results for field replicates is affected by many sources of variability within the field and laboratory environments, including sample collection, processing (filtration, preservation, transportation, and laboratory handling), and analysis. For this study, five replicates were collected concurrently in the field (sites BU-1182, BU-1186, BU-1195, PR-231, and Elk Creek below Dry Run) and analyzed separately for nutrients, nitrate, nitrite, ammonia, DOC, and alkalinity (table 1). Nitrate concentrations varied by 3.3 percent or less, alkalinity by 3.4 percent or less, and DOC by $0.4 \mathrm{mg} / \mathrm{L}$ or less. The analytical results of these replicate samples indicate low variability in field or laboratory methods. Replicate samples collected at three ground-water sites (BU-1182, BU-1195, PR-231) also were analyzed for bacteria (E. coli and total coliform). Bacterial results did not vary for 
these replicate samples (table 1). The replicate sample collected at Elk Creek below Dry Run was analyzed for ${ }^{15} \mathrm{~N}$ and ${ }^{18} \mathrm{O}$ isotope ratios; the ${ }^{15} \mathrm{~N}$ and ${ }^{18} \mathrm{O}$ isotope ratios varied by less than 3 percent.

Equipment blanks were collected and analyzed to test for bias from possible environmental contamination of equipment and to verify that decontamination procedures and laboratory protocols were adequate (Koterba and others, 1995). Equipment blanks were collected at the beginning of each field season, prior to any sample collection. An equipment blank is an aliquot of deionized water that is certified as virtually free of measured inorganic compounds and is processed through the same sampling equipment used to collect surface- and ground-water samples. The blank then is subjected to the same processing (filtration, preservation, transportation, and laboratory handling) as the surface- and ground-water samples.

Blank samples were analyzed for the same constituents as those of other samples to identify whether any detectable concentrations existed. Concentrations of nutrients, major ions, and bacteria were not detected in any of the equipment blanks.

\section{Chemical and Physical Characteristics of Ground Water and Surface Water}

Samples were collected in ground water and surface water to assess nitrate concentrations and identify likely sources of nitrate. Water samples were collected at 38 groundwater sites and 6 surface-water sites during 2003 and 2004. Table 1, at back of report, lists chemical and physical characteristics of these samples, including onsite measurements and analytical results of major ions, nutrients, bacteria, and stable isotope ratios. Table 2, at back of report, lists physical characteristics of wells sampled, including well depth, water level, aquifer type, altitude of land surface, and open interval. Table 3, at back of report, lists physical measurements at surface-water sites, including streamflow and gain or loss in flow. Nitrate concentrations in water from ground- and surfacewater sites in the Elk Creek watershed generally are low, except for concentrations in ground water in an area north of and downgradient from the City of Trenton (table 1, fig. 6). Nitrate concentrations in ground water throughout the Elk Creek watershed range from less than the reporting limit of $0.06 \mathrm{mg} / \mathrm{L}$ to $11 \mathrm{mg} / \mathrm{L}$ (table 1 ), with a mean concentration of $2.4 \mathrm{mg} / \mathrm{L}$ and a median of $0.2 \mathrm{mg} / \mathrm{L}$. Calculations of mean and median concentrations included data reported in terms of "less than" or "estimated" and used the reporting limit or value given. Water from nearly all sites in the watershed upstream from the City of Trenton and Dry Run contain nitrate concentrations near or below the laboratory reporting limit of $0.06 \mathrm{mg} / \mathrm{L}$ (green symbols in fig. 6). In the area north of and downgradient from the City of Trenton, nitrate concentrations in ground water from 12 of the 18 wells are greater than $2.0 \mathrm{mg} / \mathrm{L}$ (yellow, orange, or red symbols in fig. 6). Nitrate concentrations of less than $2.0 \mathrm{mg} / \mathrm{L}$ generally are considered to be background values, whereas greater concentrations likely result from anthropogenic sources (Rowe and others, 2004). Nitrate concentrations in water from five of the wells in this area are greater $(>6.0 \mathrm{mg} / \mathrm{L}$, orange or red symbols in fig. 6$)$ than those in the rest of the watershed.

Nitrate concentrations in the City of Trenton publicsupply wells BU-1170 and BU-1171 are 3.8 and $5.6 \mathrm{mg} / \mathrm{L}$, respectively (table 1). According to a previous study, water from these public-supply wells was sampled periodically from 1996 to 2002; nitrate concentrations decreased during that time and ranged from 3.9 to $14.3 \mathrm{mg} / \mathrm{L}$ (Todd Kehr, written commun., City of Trenton, 2003), exceeding the $10 \mathrm{mg} / \mathrm{L}$ MCL. A regional study for the entire Great Miami River watershed showed that nitrate concentrations typically range from below the detection limit of $0.041 \mathrm{mg} / \mathrm{L}$ to $5 \mathrm{mg} / \mathrm{L}$ in the GMR-BVAS (Debrewer and others, 2000).

Nitrate concentrations in the surface-water samples collected during 2003-2004 range from 0.34 to $2.4 \mathrm{mg} / \mathrm{L}$, with a mean concentration of $0.8 \mathrm{mg} / \mathrm{L}$ (table 1). At five of the six surface-water sites, nitrate concentrations are less than $1.0 \mathrm{mg} / \mathrm{L}$; whereas at the sixth site, Elk Creek at Mill Rd., near the headwaters of Elk Creek, the concentration is $2.4 \mathrm{mg} / \mathrm{L}$. In an earlier study by the City of Trenton (Todd Kehr, oral commun., 2003), nitrate concentrations ranged from less than 0.2 to $6.6 \mathrm{mg} / \mathrm{L}$ during a period of 14 months (April 1999May 2001).

Stable-isotope ratios in nitrate were determined in ground- and surface-water samples with nitrate concentrations greater than $0.06 \mathrm{mg} / \mathrm{L}$. The isotope ratios in nitrate were determined in 22 of the 38 ground-water samples and all 6 of the surface-water samples collected during 2003 and 2004. In all but three ground-water samples (BU-1180, PR230, PR-234), values of $\delta^{15} \mathrm{~N}$ in nitrate are between +2.98 to +13.41 per mil and values of $\delta^{18} \mathrm{O}$ in nitrate are between -0.15 to +8.46 per mil (table 1 ). These are close to values expected for nitrate derived from soil organic matter and ammonia fertilizer (fig. 7). Water samples from wells BU-1180 and PR-230 have low $\delta^{15} \mathrm{~N}(-6.16$ and -22.36 per mil) and low $\delta^{18} \mathrm{O}(-6.27$ and -2.5 per mil) in nitrate. Wells BU-1180 and PR-230 have open intervals at, or possibly below, the point of contact between the glacial material and the underlying bedrock. Water from these wells may be from the limestone or shale aquifer and may not be representative of surficial deposits. The bedrock aquifers, with hydraulic conductivities several orders of magnitude lower than unconsolidated deposits, typically provide minimal contribution or input to the glacial-flow system (Ohio Department of Natural Resources, 1993); therefore, isotope values in water from wells BU- 1180 and PR-230 are not included in figure 7. Water from well PR-234 has high $\delta^{15} \mathrm{~N}\left(+32.29\right.$ per mil) and $\delta^{18} \mathrm{O}(+17.72$ per mil) values in nitrate, indicating active denitrification (fig. 7). PR-234 is a 10-ft. deep uncased well in unconsolidated deposits, and the isotope values are within normal environmental ranges (Kendall, 1998). The nitrate source, however, cannot be determined as definitively for this sample because the original $\delta^{15} \mathrm{~N}$ value of the nitrate source likely was altered by denitri- 


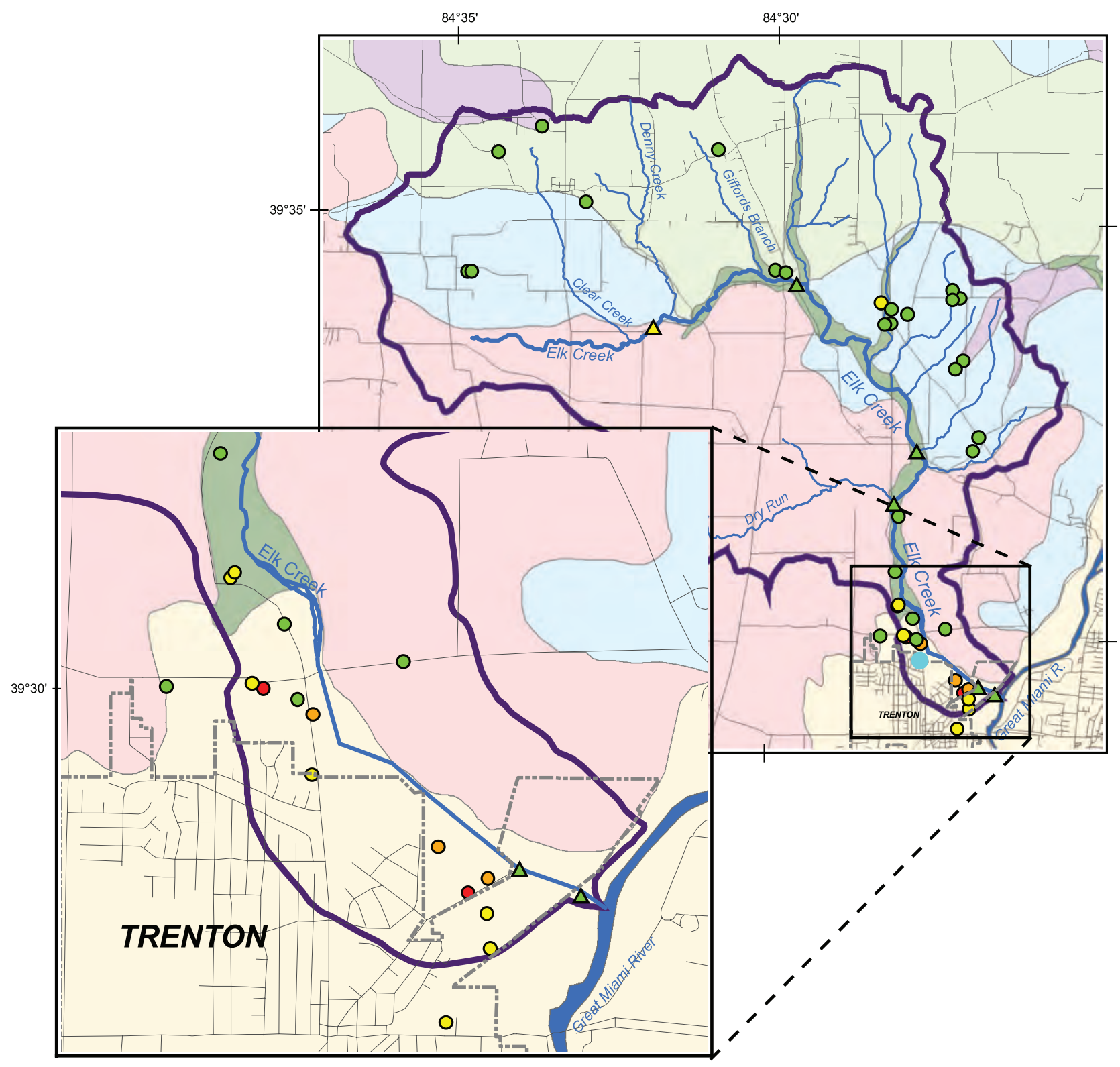

Unconsolidated aquifers from Ohio Department of Natural Resources,

North American Datum 27, South Zone (3402)

EXPLANATION

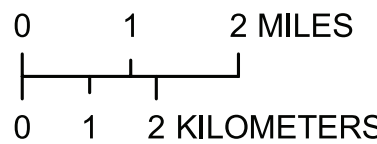

Alluvium

Great Miami River Buried Valley Aquifer System (GMR-BVAS)

Thin upland (till generally $<25$ feet thick)

Complex (till generally $>100$ feet thick)

End moraine [moderately thick $(25-100 \mathrm{ft})$ to thick (>100 ft) till]

Ground moraine [moderately thick till (25-100 ft)]

Elk Creek watershed boundary

- Trenton corporate boundary
Nitrate in Ground Water

O $<2.0 \mathrm{mg} / \mathrm{L}$

O $2.0-6.0 \mathrm{mg} / \mathrm{L}$

O $>6.0-10.0 \mathrm{mg} / \mathrm{L}$

○ $>10.0 \mathrm{mg} / \mathrm{L}$

Nitrate in Surface Water

$\Delta \quad<2.0 \mathrm{mg} / \mathrm{L}$

$\Delta \quad 2.0-6.0 \mathrm{mg} / \mathrm{L}$

Figure 6. Nitrate concentrations in ground and surface water in the Elk Creek watershed, southwestern Ohio. 


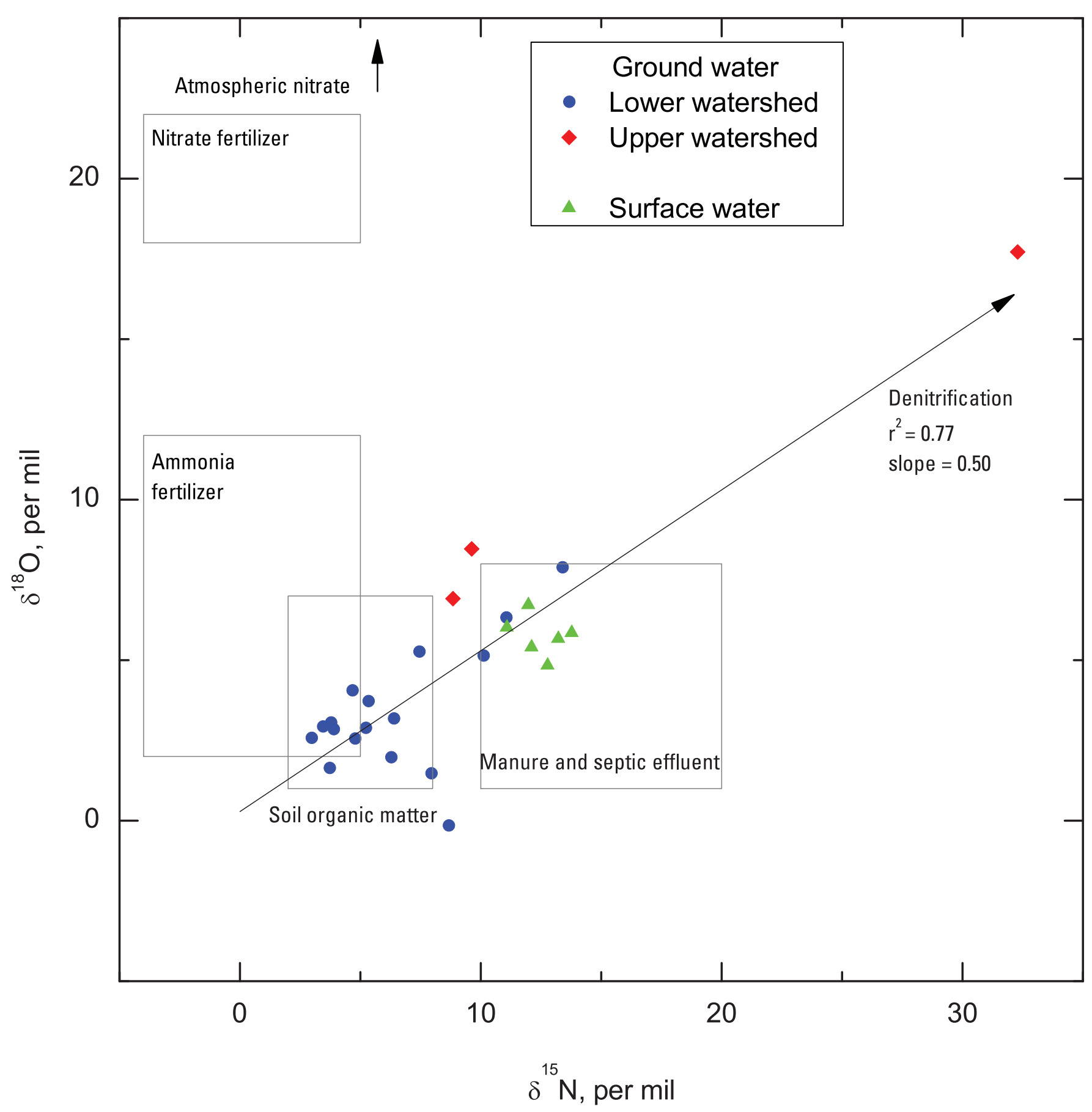

Figure 7. Nitrogen and oxygen isotope ratios of nitrate in ground and surface water in the Elk Creek watershed, southwestern Ohio. (Wells BU-1180 and PR-230 likely are completed in bedrock; isotope values from these wells are not included. Typical isotope ranges in various sources modified from Clark and Fritz, 1997.) 
fication. In surface-water samples, values of $\delta^{15} \mathrm{~N}$ in nitrate are between +11.08 and +13.78 per mil and values of $\delta^{18} \mathrm{O}$ in nitrate between +4.83 and +6.72 per mil. These values are in the range of values expected for nitrate derived from manure and septic effluent but are also near the calculated line of values for denitrified soil organic matter (fig. 7).

(Wells BU-1180 and PR-230 likely are completed in bedrock; isotope values from these wells are not included. Typical isotope ranges in various sources modified from Clark and Fritz, 1997.).

Major-ion concentrations were analyzed in samples from four wells (table 1). Wells BU-1170, BU-1186, BU-1193, and BU-1195 were selected for analysis of major ions to provide a general characterization of the water spatially distributed throughout the Elk Creek watershed. This limited amount of data indicates that ground water in the Elk Creek watershed is classified primarily as calcium-magnesium-bicarbonate type water (fig. 8). This water type is common throughout the Great Miami River watershed glacial aquifers (Eberts and George, 2000) because the source rock of the glacial deposits is primarily the underlying limestone and shale bedrock (Strobel and Faure, 1987). Chloride generally is considered a conservative constituent in ground water because it is chemically unreactive in most environments (Altman and Parizek, 1995). Concentrations of chloride range from $2.8 \mathrm{mg} / \mathrm{L}$ to $34.7 \mathrm{mg} / \mathrm{L}$ and are within background levels for southwestern Ohio (Kunze and Sroka, 2004). DOC concentrations range from 0.5 to $1.4 \mathrm{mg} / \mathrm{L}$ in water from the 38 sampled wells and

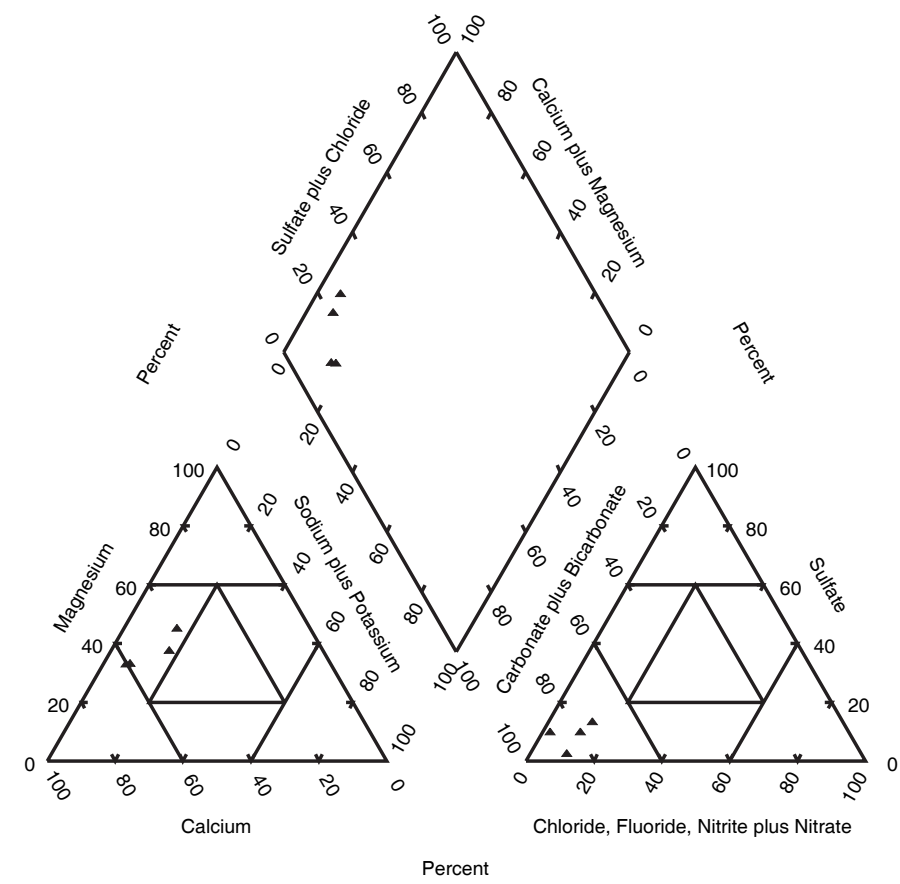

Figure 8. Trilinear diagram showing percentages of major ions in ground-water samples from unconsolidated deposits from four wells in the Elk Creek watershed, southwestern Ohio. from 1.6 to $3.1 \mathrm{mg} / \mathrm{L}$ in water from the 6 surface-water sites in Elk Creek (table 1).

Concentrations of DO range from the reporting level of $0.1 \mathrm{mg} / \mathrm{L}$ to $8.1 \mathrm{mg} / \mathrm{L}$ in water from 37 sampled wells and from 7.7 to $11.6 \mathrm{mg} / \mathrm{L}$ in water from the 6 surface-water sites in Elk Creek (table 1). The median DO concentration in the lower watershed is $5.1 \mathrm{mg} / \mathrm{L}$; in the upper watershed, it is $0.2 \mathrm{mg} / \mathrm{L}$. DO concentrations correlate positively with nitrate concentrations in Elk Creek watershed (Pearson's r $=0.84$ ). Ammonia was detected, at low concentrations ( 0.05 and $0.67 \mathrm{mg} / \mathrm{L}$ ), at only two sites in the oxic lower watershed, but was detected at 16 out of 20 sites in the anoxic upper watershed (table 1).

Phosphorus is an essential nutrient for the growth of plants, and orthophosphate is the most- abundant form of phosphorus naturally occurring in surface water (Kentucky Division of Water, 2003). Orthophosphate and phosphorus concentrations in water from the six surface-water sites in Elk Creek are either at or below the detection level of $0.02 \mathrm{mg} / \mathrm{L}$ (table 1).

Under natural conditions, orthophosphate occurs at low concentrations $(0.02 \mathrm{mg} / \mathrm{L})$ in shallow ground water (U.S. Geological Survey, 1999). Orthophosphate concentrations in water from all but four wells are less than this background level (table 1). Orthophosphate concentrations in water from four wells in the lower watershed (BU-1175, BU-1176, BU-1179, and BU-1182) exceed this background level, ranging from $0.067 \mathrm{mg} / \mathrm{L}$ to $0.13 \mathrm{mg} / \mathrm{L}$; the range suggests a possible anthropogenic source.

Phosphorus concentrations in water from all but five wells are less than the detection level of $0.04 \mathrm{mg} / \mathrm{L}$ (table 1). Phosphorus concentrations that are greater than the detection level were in water samples from wells just north of and downgradient from the City of Trenton (BU-1172, BU-1175, BU-1176, BU-1179, and BU-1182) and range from $0.08 \mathrm{mg} / \mathrm{L}$ to $0.14 \mathrm{mg} / \mathrm{L}$. Obvious upgradient wastewater sources of orthophosphate and phosphorus are not apparent; however, detectable concentrations of orthophosphate and phosphorus may be related to onsite or adjacent-area land-use/ management practices (including livestock production/grazing or application of phosphate-rich fertilizers).

Ammonia concentrations in water from the 6 surfacewater samples and 22 of the 38 ground-water samples are less than the detection level of $0.04 \mathrm{mg} / \mathrm{L}$ (table 1). All but two wells in the lower watershed contain ammonia concentrations below the reporting level of $0.04 \mathrm{mg} / \mathrm{L}$; water from BU-1180 and BU-1181 contains ammonia concentrations of 0.67 and $0.05 \mathrm{mg} / \mathrm{L}$, respectively. Wells in the upper watershed have a wide range of ammonia concentrations, from below the reporting level of 0.04 to $1.67 \mathrm{mg} / \mathrm{L}$. Ammonia concentration in ground water in the upper watershed does not correlate with screened or open interval or aquifer type. The presence of detectable ammonia directly corresponds to the absence of detectable levels of nitrate and to low DO concentrations.

Water samples collected from 37 wells during 2003 and 2004 were analyzed for E. coli and total coliform bacteria. The 
presence of E. coli provides direct evidence of fecal contamination from warm-blooded animals. Total coliform indicates a vulnerability to surface contamination. E. coli was detected in water from 1 well, BU-1197, and total coliform was detected in water from 15 wells (table 1). The spigot orifice of BU-1197 is at ground level and is in direct contact with soil and detritus; therefore the presence of $E$. coli in water from this well could be a result of surface contaminants and may not be representative of $E$. coli concentration in the aquifer. Total coliform in water from 15 wells ranges from 2 to $85 \mathrm{col} / 100 \mathrm{~mL}$. Wells that contain detected concentrations of total coliform are spatially distributed throughout the watershed. Total coliform does not significantly correlate with any other water quality characteristic, well depth, or type of aquifer.

Streamflow measurements correspond to an annual exceedence of approximately 85 percent when compared to a previous low-flow study of Elk Creek (Straub, 2001). Elk Creek was a gaining stream throughout most of its reach during this study. Streamflow during this low-flow period increased from the most-upstream site $\left(0.34 \mathrm{ft}^{3} / \mathrm{s}\right)$ to downstream from the production wellfield $\left(1.95 \mathrm{ft}^{3} / \mathrm{s}\right)($ table 3$)$. A losing reach was identified toward the mouth of Elk Creek. Streamflow decreased by $1.23 \mathrm{ft}^{3} / \mathrm{s}$ between the wellfield and the mouth of Elk Creek. This amount of streamflow loss is substantially greater than the average daily well field pumping rate $\left(0.36 \mathrm{ft}^{3} / \mathrm{s}\right)$ (Todd Kehr, oral commun., 2003). Therefore, water lost by the stream cannot be attributed only to ground water withdrawals by the production wells. The loss also may be related to the intersection of the Elk Creek Valley with the GMR-BVAS. Elk Creek water may be recharging the GMR-BVAS near the Great Miami River or there may be additional flow paths not identified.

The two outfalls below Dry Run had streamflows of 0.0056 and $0.014 \mathrm{ft}^{3} / \mathrm{s}$ (table 3 ). The margin of error associated with the discharge measurements ranges from \pm 5 to \pm 8 percent.

\section{Evaluation of Nitrate Concentrations and Sources in the Elk Creek Watershed}

Concentrations of nitrate in ground water in the upper Elk Creek watershed are generally lower (median of $0.06 \mathrm{mg} / \mathrm{L}$ ) than concentrations in ground water in the lower Elk Creek watershed (median of $4.2 \mathrm{mg} / \mathrm{L}$ ). The difference between recorded nitrate concentrations in the upper and lower watersheds possibly is caused by a different source of nitrate in the lower watershed, the mixing of multiple aquifer waters, or changes in geochemical reactions resulting from differing DO content and the type of aquifer.

Nitrate concentrations in ground water were measured in City of Trenton public-supply wells and in surface water in Elk Creek adjacent to the Northeast Wellfield, from 1996 to 2002 (Todd Kerr, written commun., 2003). Values were recorded weekly to quarterly during these 6 years. Concentration of nitrate in the public-supply wells ranged from 3.9 to $14.3 \mathrm{mg} / \mathrm{L}$, and concentration in surface water ranged from $<0.2$ to $6.6 \mathrm{mg} / \mathrm{L}$ during the same period.

In the 2003-2004 study, nitrate concentrations in Elk Creek samples upstream from and adjacent to the City of Trenton Northeast Wellfield were $0.74 \mathrm{mg} / \mathrm{L} 0.34 \mathrm{mg} / \mathrm{L}$, respectively. The wellfield is in the lower Elk Creek watershed. In contrast, water samples collected from the City of Trenton public-supply wells BU-1170 and BU-1171 (fig. 2) in 2003 and 2004 contained nitrate concentrations of 3.8 and $5.6 \mathrm{mg} / \mathrm{L}$, respectively; nitrate concentration ranged from 3.9 to $14.3 \mathrm{mg} / \mathrm{L}$ in the samples collected from 1996 through 2002.

Streamflow in Elk Creek increases along the entire mainstem, except for a short segment between the City of Trenton Northeast Wellfield and the confluence with the Great Miami River (table 3). In this short downstream segment, flow decreases substantially $\left(1.23 \mathrm{ft}^{3} / \mathrm{s}\right)$ and is a greater decrease than can be attributed to the average daily withdrawal rate of $0.36 \mathrm{ft}^{3} / \mathrm{s}$. The ranges of $\delta^{15} \mathrm{~N}(+11.08$ to +13.78$)$ and $\delta^{18} \mathrm{O}$ $(+4.83$ to +6.72$)$ (table 1) values for nitrate in the stream, however, are higher than the median ground-water values for $\delta^{15} \mathrm{~N}$ and $\delta^{18} \mathrm{O}(+6.35$ and +3.15 per mil, respectively $)$ in the lower watershed (fig. 7).

Water-quality information from the Elk Creek watershed indicates that nitrate concentrations are low in ground and surface water throughout the watershed. An exception is an area in the southeast tip of the watershed, north of and downgradient from the City of Trenton. Four possible and general sources of nitrate in the unconsolidated deposits in this area are Elk Creek, atmospheric deposition, manure and septic effluent, fertilizers, and soil organic matter. Atmospheric deposition is considered a possible source of nitrate but data collected during this study indicate that atmospheric deposition was not a measurable contributor in the Elk Creek watershed (fig. 7).

Even though streamflow measurements indicate recharge to ground water from Elk Creek near the City of Trenton public-supply wells, induced infiltration of surface water from Elk Creek is likely only a partial source of recharge to these wells. Nitrate concentrations in Elk Creek are much lower than those in water from the public supply-wells, indicating another source of water with high concentrations of nitrate is recharging the wells. Stable isotope values are higher in Elk Creek than in water from the public-supply wells, however, indicating that yet and additional source of water with lower isotope values is recharging the wells. The low concentrations of nitrate and high stable isotope values in nitrate in Elk Creek are a likely result of denitrified ground water that discharges to Elk Creek throughout much of the watershed. Some decrease in stream nitrate concentration can be attributed to aquaticplant uptake, but isotopic fractionation by plant uptake is negligible (Kendall, 1998). 
Stable isotope values in the upper part of Elk Creek watershed have been affected by denitrification, as indicated by low DO concentrations, high dissolved iron and manganese concentrations, and high bicarbonate concentrations (table 1). DO concentrations in wells in the lower watershed sand and gravel GMR-BVAS and alluvial aquifers are high, indicating an oxic environment. The high DO levels (median of $5.1 \mathrm{mg} /$ L) may be the result of rapid infiltration of local precipitation through the soil (Freeze and Cherry, 1979). Wells in the upper watershed are open, or screened, in sand and gravel layers within end or ground moraines or in alluvial deposits of limited extent. DO concentrations in wells in the upper watershed are low (median of $0.2 \mathrm{mg} / \mathrm{L}$ ), indicating an anoxic environment. The median nitrate concentration in the upper watershed $(0.06 \mathrm{mg} / \mathrm{L})$ is less than that in the lower watershed

$(4.2 \mathrm{mg} / \mathrm{L})$; the median ammonia concentration in the upper watershed $(0.36 \mathrm{mg} / \mathrm{L})$ is greater than that in the lower watershed $(<0.04 \mathrm{mg} / \mathrm{L})$. These data indicate that denitrification may be occurring in the upper watershed and that nitrification of ammonium may be occurring in the lower watershed.

Denitrification is one outcome of the bacterial oxidation of organic carbon. Organic carbon is a common, and possibly required, nutrient for denitrifying bacteria (Puckett and Cowdery, 2002; Trudell and others, 1986). Bacterially mediated denitrification does not occur in oxic conditions. Denitrification occurs in a reducing environment, such as in the upper watershed, in the presence of an available electron donor such as organic carbon. In such a reducing environment, nitrate becomes the preferential electron receptor, leading to denitrification (Puckett and Cowdery, 2002). Once the nitrate is consumed, manganese oxide and iron oxide become the preferred terminal electron receptors, and manganese and iron can enter solution. In this study four sites were sampled for major ions (table 1). Denitrification may be a cause of higher dissolved iron $(1,610$ and $1,970 \mu \mathrm{g} / \mathrm{L})$ and higher dissolved manganese $(8.5$ and $17.3 \mu \mathrm{g} / \mathrm{L})$ at the two sites in the upper watershed compared to values for dissolved iron $(<8$ and $13 \mu \mathrm{g} / \mathrm{L}$ ) and dissolved manganese (E0.3 and $3.0 \mu \mathrm{g} / \mathrm{L}$ ) at the two sites in the lower watershed,

Concentrations of DOC, which serves as fuel for the denitrification process, were uniform throughout the watershed. Bicarbonate is the most-easily measured end product of denitrification and is conservative (Trudell and others, 1986); it can indicate denitrification. Bicarbonate was higher in the upper watershed than in the lower watershed and is negatively correlated with nitrate (Pearson's $r=-0.55$ ).

No discrete point sources of nitrates, ammonia, or nutrients that flowed into Elk Creek (such as treatment plants, industrial effluent pipes, or conduits) were found. The two outfalls measured in this study carried surface-water drainage, and the City of Trenton sewage-treatment-plant outfalls discharge into the Great Miami River. Nonpoint sources typically contribute most of the instream nutrient loads in the Great Miami River Basin (Reutter, 2003).

The consistent ground-water chemistry, as displayed in the trilinear diagram (fig. 8) and chloride concentrations (table 1), indicate that ground water sampled for this study came from aquifers with similar geochemical characteristics. The ${ }^{15} \mathrm{~N}$ and ${ }^{18} \mathrm{O}$ isotope ratios suggest that naturally occurring soil organic matter and ammonia fertilizers from current or prior agricultural activities are the most-probable sources of nitrate to the ground water and Elk Creek (fig. 7). Several factors though can complicate the evaluation of nitrate sources based on ${ }^{15} \mathrm{~N}$ and ${ }^{18} \mathrm{O}$ isotopes.

Ammonium volatilization, prior to nitrification of ammonium, from ammonia fertilizer can affect the source signature, producing an elevated $\delta^{15} \mathrm{~N}$ value in the resultant nitrate (Flipse and Bonner, 1985). Nitrification of ammonium occurs in oxic ground water such as that in the lower watershed. This is a possible mechanism for the presence of nitrate in the aquifer. An exchange or mixing of nitrate from naturally occurring soil organic matter with nitrate from ammonia fertilizer further can complicate the isotopic analysis. The relative contribution of nitrate from ammonia fertilizer cannot be determined because of a lack of information about the areal extent and application rates of the fertilizer. Other nitrate sources such as septic effluent, atmospheric deposition, and nitrate fertilizers are known contributors to total nitrate loads.

The data collected during this study, however, show that the likely sources of observed nitrate in the Elk Creek watershed are soil organic matter and/or ammonia fertilizer (fig. 7). Isotopic enrichment can shift isotopic values from the typical range of one source to the typical range of a different source. Enriched $\delta^{15} \mathrm{~N}$ and $\delta^{18} \mathrm{O}$ values that do not plot within the typical ranges for ammonia fertilizer or soil organic matter do plot along or near the line of denitrification. That the $\delta^{15} \mathrm{~N}$ and $\delta^{18} \mathrm{O}$ values plot along the denitrification line (fig. 7 ) indicates that the origination of nitrate for all sampled sites is the same. The slope of this line, $0.5\left(\mathrm{r}^{2}=0.77\right)$, shows enrichment of ${ }^{15} \mathrm{~N}$ to ${ }^{18} \mathrm{O}$ by a factor of 2 to 1 . This $2: 1$ ratio is consistent with values typically reported for isotopic enrichment by denitrification (Mengis and others, 1999; Kendall, 1998; Böttcher and others, 1990).

Surface-water isotope values plot along or near the denitrification line related to soil organic matter and ammonia fertilizer; they also plot within the range of manure and septic effluent (fig. 7). Livestock in pastures and barn yards near Elk Creek and its tributaries are potential sources of this surfacewater nitrate. The isotopic evidence indicates the sources of nitrate in the ground water are soil organic matter and the nitrification of ammonium from ammonia fertilizer.

\section{Summary}

Nitrate concentrations in ground water within the Elk Creek watershed north of Trenton, Ohio have exceeded the maximum contaminant level of $10 \mathrm{mg} / \mathrm{L}$. The USGS, in cooperation with the Miami Conservancy District, conducted a study to evaluate the levels of nitrate concentrations and their sources. During the late summer and fall of 2003 and 2004, 38 ground-water 
and 6 surface-water samples were collected and analyzed for dissolved nutrients, dissolved organic carbon, and alkalinity. Thirty-seven ground-water wells were analyzed for E. coli and total coliform bacteria. All samples with nitrate concentrations greater than $0.06 \mathrm{mg} / \mathrm{L}$ subsequently were analyzed for $\delta^{15} \mathrm{~N}$ and $\delta^{18} \mathrm{O}$ values.

Ground-water nitrate concentrations ranged from below the reporting limit of $0.06 \mathrm{mg} / \mathrm{L}$ to $11 \mathrm{mg} / \mathrm{L}$, with lower values in the upper watershed (median value of $0.06 \mathrm{mg} / \mathrm{L}$ ) when compared to those in lower watershed (median value of $4.2 \mathrm{mg} / \mathrm{L}$ ). The difference in nitrate concentrations between the upper and lower watershed is attributable to denitrification in the shallow ground water. The levels of dissolved organic carbon and low dissolved oxygen in the upper watershed are suitable conditions for denitrification. High bicarbonate levels, an end-product of the denitrification process, also are present in the upper watershed.

Nitrate concentrations within the upper and lower watersheds do not appear to be related to land use or the mixing of multiple aquifer waters. An evaluation of land use in the watershed revealed that the predominant use is agricultural (93 percent), and no point sources of nitrates were identified. Furthermore, bacterial analyses provided no evidence of septic contamination. An analysis of limited major-ion concentration data indicated the ground water was a homogeneous calciummagnesium-bicarbonate water type throughout the watershed.

The likely sources of nitrate to the watershed, based on isotopic analysis of oxygen and nitrogen in the dissolved nitrate, are soil organic matter and ammonia fertilizer. The ${ }^{15} \mathrm{~N}$ and ${ }^{18} \mathrm{O}$ values (excluding outliers) ranged from +2.98 to +32.29 , and -0.15 to +17.72 per mil, respectively. The $\delta^{15} \mathrm{~N}$ and $\delta^{18} \mathrm{O}$ values for most ground-water samples plot near the typical ranges for soil organic matter and ammonia fertilizer. Despite a large range of isotope values and concentrations, the sources of nitrate for all samples analyzed in this study are the same. Those samples that plot outside these typical ranges plot along a denitrification line that leads back to pre-denitrification values that are also in the soil organic matter and ammonia fertilizer ranges.

\section{Acknowledgments}

The authors thank the personnel of the City of Trenton and the Ohio Department of Natural Resources for providing background data and information essential to this project. Thanks are also expressed to the residents of the Elk Creek watershed for their willingness to participate in this project.

\section{References Cited}

American Public Health Association, American Water Works Association, and Water Pollution Control Federation, 1992, Standard methods for the examination of water and wastewater $\left(18^{\text {th }}\right.$ ed.): Washington D.C., American Public Health Association [variously paginated].

Altman, S.J., and Parizek, R.R., 1995, Dilution of nonpointsource nitrate in ground water: Journal of Environmental Quality, v. 24, p. 707-718.

Battaglin, W.A., Kendall, C., Chang, C.C.Y., Silva, S.R., and Campbell, D.H., 2001, Chemical and isotopic evidence of nitrogen transformation in the Mississippi River, 1997-98: Hydrological Processes v. 15, no. 7, p. 1,285-1,300.

Böhlke, J.K., and Denver, J.M., 1995, Combined use of groundwater dating, chemical, and isotopic analyses to resolve the history and fate of nitrate contamination in two agricultural watersheds, Atlantic Coastal Plain, Maryland: Water Resources Research, v. 31, no. 9, p. 2,319-2,339.

Böttcher, J., Strebel, O., Voerkelius, Susanne., and Schmidt, H.L., 1990, Using isotope fractionation of nitrate-nitrogen and nitrate-oxygen for evaluation of microbial denitrification in a sandy aquifer: Journal of Hydrology, v. 114, p. 413-424.

Brockman, C.S., 1998, Physiographic regions of Ohio: Ohio Department of Natural Resources, Division of Geological Survey, 1 sheet.

Clark, I.D., and Fritz, Peter, 1997, Environmental isotopes in hydrogeology: Boca Raton, Fla., Lewis Publishers, p. 148154.

Coplen, T.B., 1988, Normalization of oxygen and hydrogen isotope data: Chemical Geology (Isotope Geoscience Section), v. 72, p. 293-297.

Coplen, T.B., 1994, Reporting of stable hydrogen, carbon, and oxygen isotopic abundances: Pure and Applied Chemistry, v. 66, p. $273-276$.

Coplen, T.B., 2006 (updated), Quality assurance plan of the Reston stable isotope laboratory, accessed May 4, 2006 at http://www.isotopes.usgs.gov/Quality.htm

Cross, W.P., 1967, Drainage areas of Ohio streams supplement to gazetteer of Ohio streams: Ohio Water Plan Inventory Report 12a, $61 \mathrm{p}$.

Debrewer, L.M., Rowe, G.L., Reutter, D.C., Moore, R.C., Hambrook, J.A., and Baker, N.T., 2000, Environmental setting and effects on water quality in the Great and Little Miami River Basins, Ohio and Indiana: U.S. Geological Survey Water-Resources Investigation Report 99-4201, 98 p. 
Eberts, S.M., and George, L.L., 2000, Regional ground-water flow and geochemistry in the Midwestern Basins and Arches aquifer system in parts of Indiana, Ohio, Michigan, and Illinois: U.S. Geological Survey Professional Paper 1423-C, 103 p.

Fenneman, N.M., 1938, Physiography of eastern United States: New York, McGraw-Hill Co., 714 p.

Flipse, W.J., and Bonner, F.T., 1985, Nitrogen-isotope ratios of nitrate in ground water under fertilized fields, Long Island, New York: Ground Water v. 23, no. 1, p. 59-67.

Francy, D.S., Jones, A.L., Myers, D.N., Rowe, G.L. Jr., Eberle, Michael, and Sarver, K.M., 1998, Quality-assurance/quality-control manual for collection and analysis of waterquality data in the Ohio District, U.S. Geological Survey: U.S. Geological Survey Water-Resources Investigations Report 98-4057, 71 p.

Freeze, R.A., and Cherry, J.A., 1979, Groundwater: Englewood Cliffs, N.J., Prentice-Hall Inc., 604 p.

Kendall, C., 1998, Tracing nitrogen sources and cycling in catchments, in Kendall, C., and McDonnell, J.J., eds., Isotope tracers in catchment hydrology: Amsterdam, Elsevier, p. 519-576.

Kendall, C., Campbell, D.H., Burns, D.A., Shanley, J.B., Silva, S.R., and Chang, C.C.Y., 1995, Tracing sources of nitrate in snowmelt runoff using the oxygen and nitrogen isotopic compositions of nitrate-Pilot studies at three catchments, in Biogeochemistry of Seasonally Snow-Covered Catchments, Proceedings of a Boulder Colorado Symposium, July 1995: International Association of Hydrological Sciences Publication 228, p. 339-347.

Kentucky Division of Water, 2003, Expanded groundwater monitoring for nonpoint source pollution assessment in the Salt and Licking River Basins Final Report: NPS Project Number 96-16, 94 p., accessed 8/15/06 at http://www.water. ky.gov/gw/monitoring/gwreports/GWB-GWQ-NPS-BMU_ reports.htm.htm

Klaer, F.H., Jr., and Thompson, D.G., 1948, Ground-water resources of the Cincinnati area, Butler and Hamilton Counties, Ohio: U.S. Geological Survey Water-Supply Paper 999, $168 \mathrm{p}$.

Komor, S.C., and Anderson, H.W., 1993, Nitrogen isotopes as indicators of nitrate sources in Minnesota sand-plain aquifers: Ground Water, v. 31, no. 2, p. 260-270.

Koterba, M.T., Wilde, F.D., and Lapham, W.W., 1995, Ground-water data-collection protocols and procedures for the National Water-Quality Assessment Program-Collection and documentation of water-quality samples and related data: U.S. Geological Survey Open-File Report 95-399, $113 \mathrm{p}$.
Kunze, A.E., and Sroka, B.N., 2004, Effects of highway deicing chemicals on shallow unconsolidated aquifers in Ohio-Final report: U.S. Geological Survey Scientific Investigations Report 2004-5150, 187 p.

Mariotti, A., 1983, Atmospheric nitrogen is a reliable standard for natural $15 \mathrm{~N}$ abundance measurements: Nature, v. 303, p. 685-687.

Mengis, M., Schiff, S.L., Harris, M., English, M.C., Aravena, R., Elgood, R.J., and MacLean, A., 1999, Multiple geochemical and isotopic approaches for assessing ground water $\mathrm{NO}_{3}$-elimination in a riparian zone: Ground Water, v. 37 no. 3 , p. $448-457$.

Miami Conservancy District, 2001, State of the aquifer, Lower Great Miami Sub-basin: Report 01-01, 48 p.

Miami Conservancy District, 2002, State of the Upper Great Miami Subwatershed: Report 02-08A, 89 p.

Norris, S.E., and Spieker, A.M., 1966, Ground-water resources of the Dayton area, Ohio: U.S. Geological Survey WaterSupply Paper 1808, 167 p.

Ohio Department of Natural Resources, 1967, Drainage areas of Ohio streams supplement to gazetteer of Ohio streams: Ohio Water Plan Inventory Report 12a, 61 p.

Ohio Department of Natural Resources, 1993, Phase 1 Study of ground water conditions near Trenton, Ohio, January 14, 1993.

Ohio Department of Natural Resources, 1994, Land coverButler County, metadata found at http://www.dnr.state. oh.us/gims/response. asp? county=Select\&category $=$ LandUs e\%2FLand Cover.

Ohio Department of Natural Resources, 1999, Ground Water Investigation Report. In the Vicinity of Trenton, Ohio Butler County, St. Clair Township technical report of investigation 99-2, December, 1999.

Pletsch, B.A., and Schumann, T.L., 2004, Ground-water quality data from Elk Creek watershed near Trenton, Ohio, 2003: Miami Conservancy District, 19 p., accessed 8/15/06 at http://www.miamiconservancy.org/resources/documents/ FinalReport-PhaseI05-04.pdf

Pritt, J.W., and Raese, J.W., 1995, Quality assurance/quality control manual-National Water Quality Laboratory: U.S. Geological Survey Open-File Report 95-443, 35 p.

Puckett, L.J., and Cowdery, T.K., 2002, Transport and fate of nitrate in a glacial outwash aquifer in relation to ground water age, land use practices, and redox processes: Journal of Environmental Quality, v. 31, no. 3, p. 782-796. 
Reutter, D.C., 2003, Nitrogen and phosphorus in streams of the Great Miami River Basin, Ohio, 1998-2000: U.S. Geological Survey Water Resources Investigations Report 02-4297, 67 p.

Rowe, G.L., Jr., Reutter, D.C., Runkle, D.L., Hambrook, J.A., Janosy, S.D., and Hwang, L.H., 2004, Water quality in the Great and Little Miami River Basins, Ohio and Indiana, 1999-2001: U.S. Geological Survey Circular 1229, 40 p.

Schmidt, J.J., 1986, Ground-water resources of Butler County: Ohio Department of Natural Resources, 1 sheet, scale 1:62,500.

Shearer, L.A., Goldsmith, J.R., Young C., Kearns, O.A., Tamplin, B.R., 1972, Methemoglobin levels in infants in an area with high nitrate water supply: American Journal of Public Health, v. 62, p. 1,174-1,180.

Sheets, R.A., Darner, R.A., and Whitteberry, B.L., 2002, Lag times of bank infiltration at a well field, Cincinnati, Ohio, USA: Journal of Hydrology, v. 266, p. 162-174.

Straub, D.E., 2001, Low-flow characteristics of streams in Ohio through water year 1997: U.S. Geological Survey Water Resources Investigations Report 01-4140, 415 p.

Strobel, M.L., and Faure, Gunter, 1987, Transport of indicator clasts by ice sheets and the transport half-distance-A contribution to prospecting for ore deposits: Journal of Geology, v. 95, p. 687-697.

Trudell, M.R., Gillham, R.W., and Cherry, J.A., 1986, An in-situ study of the occurrence and rate of denitrification in a shallow unconfined sand aquifer: Journal of Hydrology, v. 83 , p. $251-268$.
U.S. Census Bureau, 2000, Population, housing units, area and density-2000, accessed October 2005 at http://factfinder.census.gov/servlet/GCTTable?_bm=y\&geo_id=04000US39\&-box_head_nbr=GCT-PH1\&-ds_ name=DEC_2000_SF1_U\&-format $=S T-7$

U.S. Environmental Protection Agency, 2000, Membrane filter method for the simultaneous detection of total coliforms and Escherichia coli in drinking water: Cincinnati, Ohio, EPA 600-R-00-013, 20 p.

U.S. Environmental Protection Agency, 2003, National Primary Drinking Water Standards: Office of Water, EPA 816-F-03-016, accessed January $2005^{1}$ at $h t t p: / / w w w$. epa.gov/safewater/standards.html

U.S. Geological Survey, 1999, The quality of our nation's waters - nutrients and pesticides: U.S. Geological Survey Circular 1225, $82 \mathrm{p}$.

Walker, A.C., 1986, Ground-water resources of Preble County: Ohio Department of Natural Resources, 1 sheet, scale 1:62,500.

Wilde, F.D., Radtke, D.B., Gibs, Jacob, and Iwatsubo, R.T., eds., 1999, National field manual for the collection of waterquality data-Collection of water samples: U.S. Geological Survey Techniques of Water-Resources Investigations, book 9, chap. A4, 156 p.

Wilde, F.D., Radtke, D.B., Gibs, Jacob, and Iwatsubo, R.T., eds., 2004, National field manual for the collection of waterquality data-Processing of water samples: U.S. Geological Survey Techniques of Water-Resources Investigations, book 9, chap. A5, 149 p. 


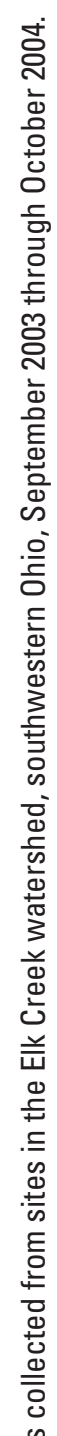

\begin{tabular}{|c|c|c|c|c|}
\hline 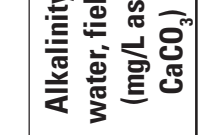 & 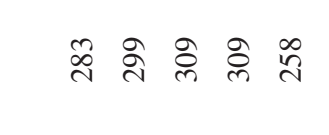 & 8 & 85 & $\frac{2}{0}=$ \\
\hline 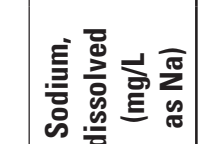 & $\cong \ldots$ & & & $\cdots \cong$ \\
\hline 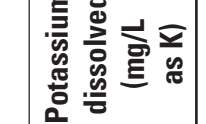 & 多 & & & 1 学 \\
\hline 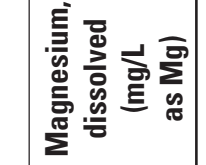 & 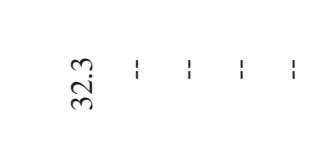 & & & $\because \frac{\circ}{\pi}$ \\
\hline 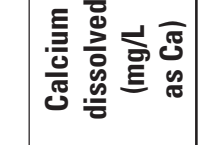 & g & & & " \\
\hline$\underline{\underline{z}}$ & 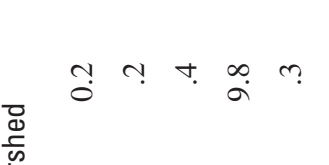 & 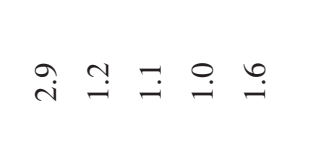 & 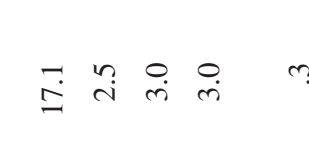 & $n n=$ \\
\hline & 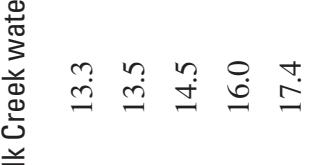 & 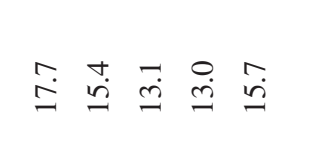 & 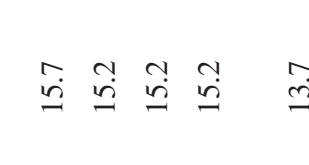 & 果里 \\
\hline 譥 & $8: \overline{0}$ & $\because=$ & $\because$ \% & \\
\hline 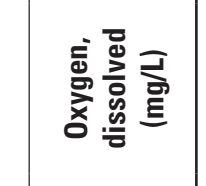 & $988=2$ & 87280 & $-9 q$ & \pm 0 \\
\hline 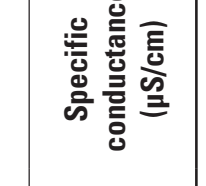 & 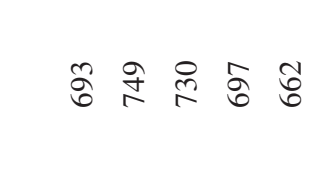 & 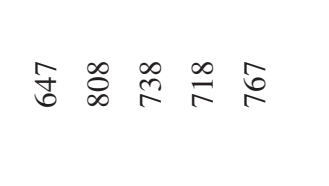 & 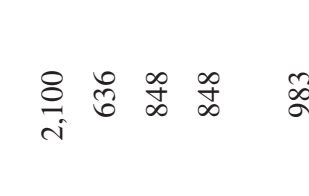 & 20 \\
\hline & 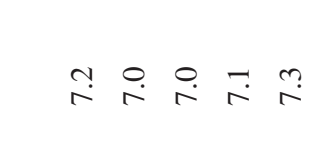 & $\bar{F}=28:$ & 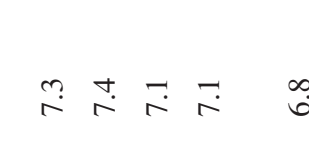 & $=2=$ \\
\hline 高 & 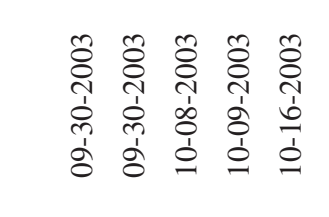 & 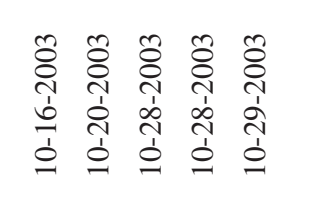 & 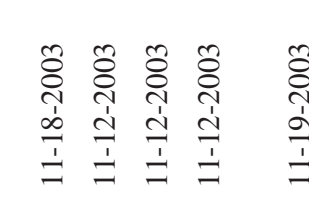 & \\
\hline & 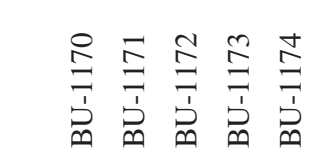 & & 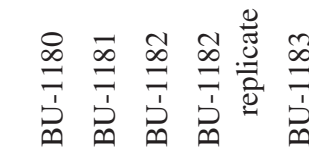 & \\
\hline
\end{tabular}




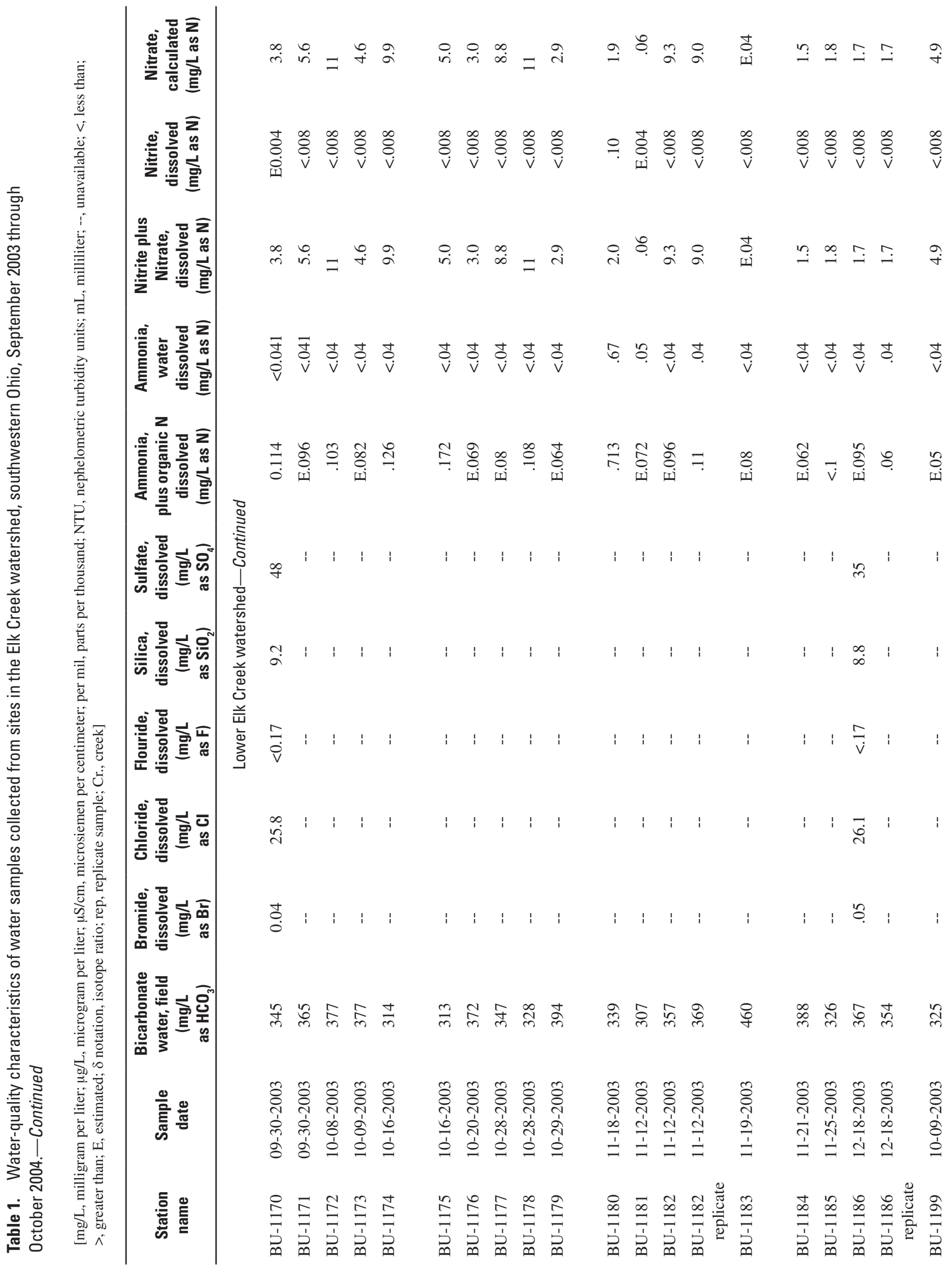




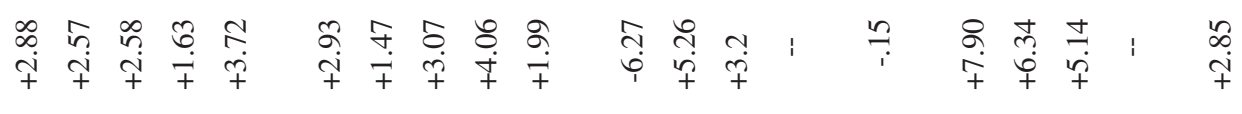

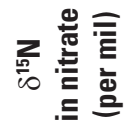

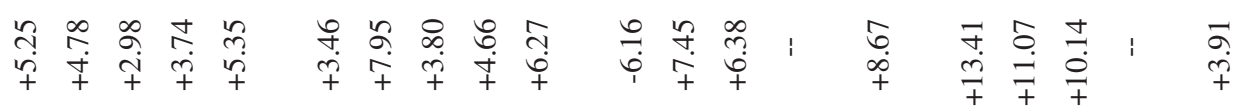

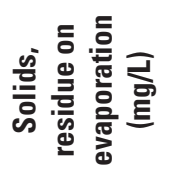

$\stackrel{\infty}{\infty}$

$\overrightarrow{0}$

它

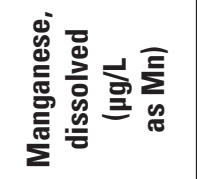

@̊?

흐

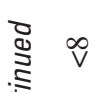

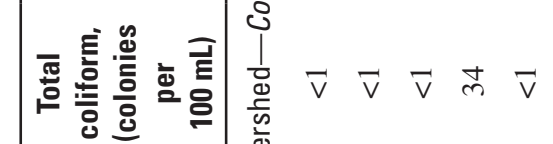

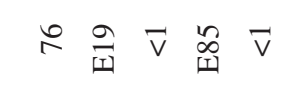

I $\overrightarrow{\mathrm{I}}$

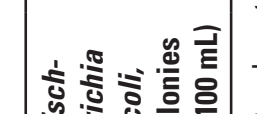

3

चु

.

$\begin{array}{llllll}\vec{v} & \vec{v} & \vec{v} & \vec{v} & \vec{v}\end{array}$

$\begin{array}{lllll}\vec{v} & \vec{v} & \vec{v} & \vec{v} & \nabla\end{array}$ $\vec{v}-\vec{v}-\vec{v}$ 형 死递至

$\stackrel{\infty}{0} \cdot a, \infty$.

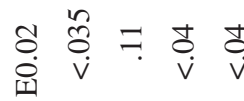

$\stackrel{0}{0} \stackrel{d}{0}$,

ก. . . .

$\begin{array}{cccc}\bar{v} & \bar{v} & \bar{v} & \bar{v}\end{array}$

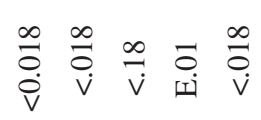

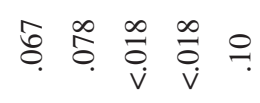

$\stackrel{\infty}{\sigma} \underset{\dot{v}}{\stackrel{\infty}{\sigma}} \stackrel{n}{?}$

$\stackrel{\infty}{ᄒ}$

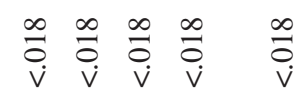

施的

总兽

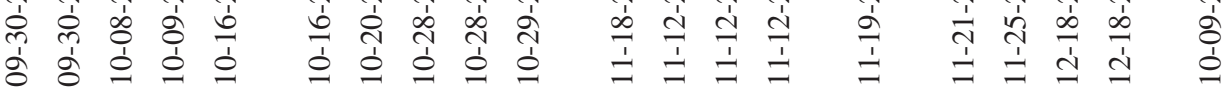




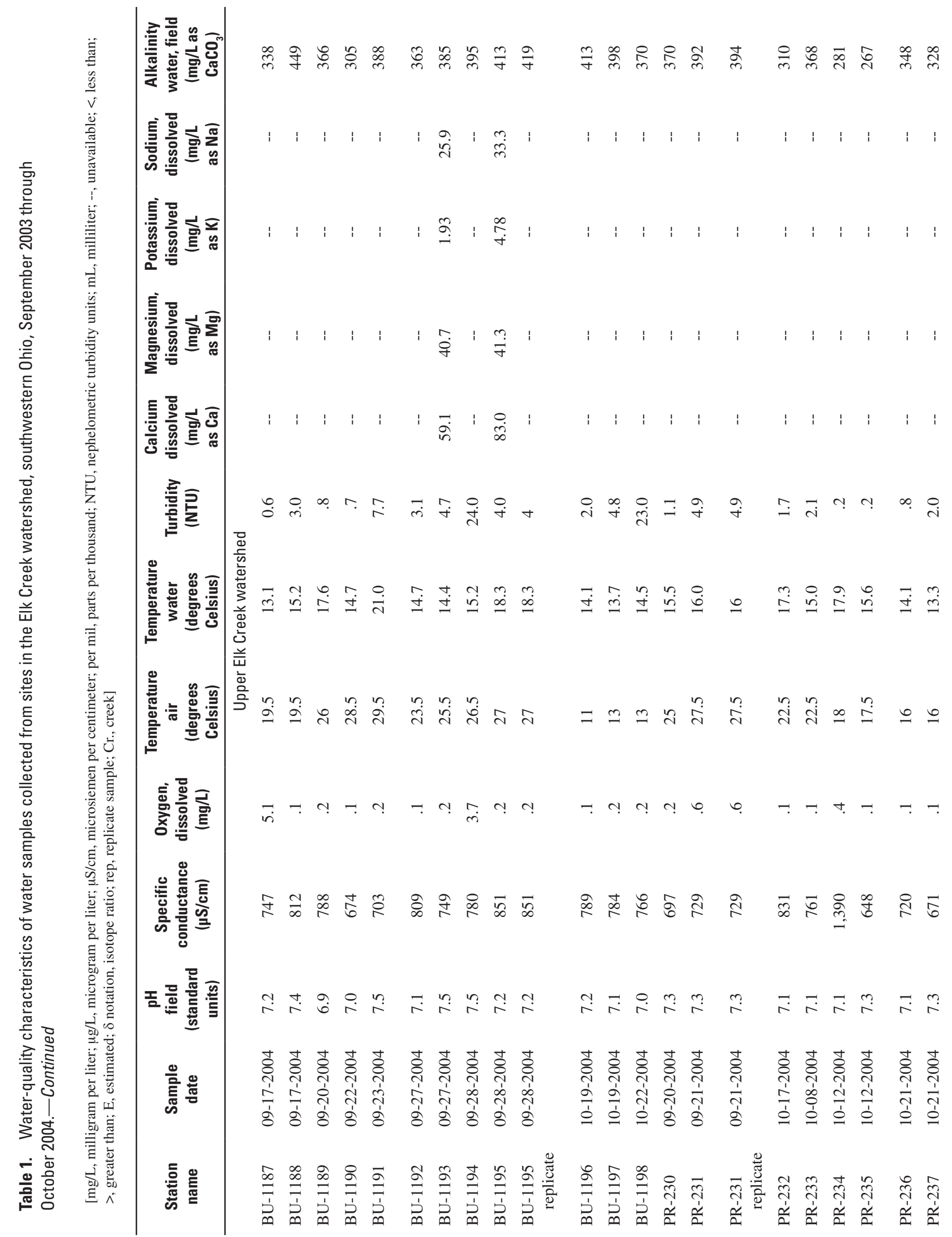




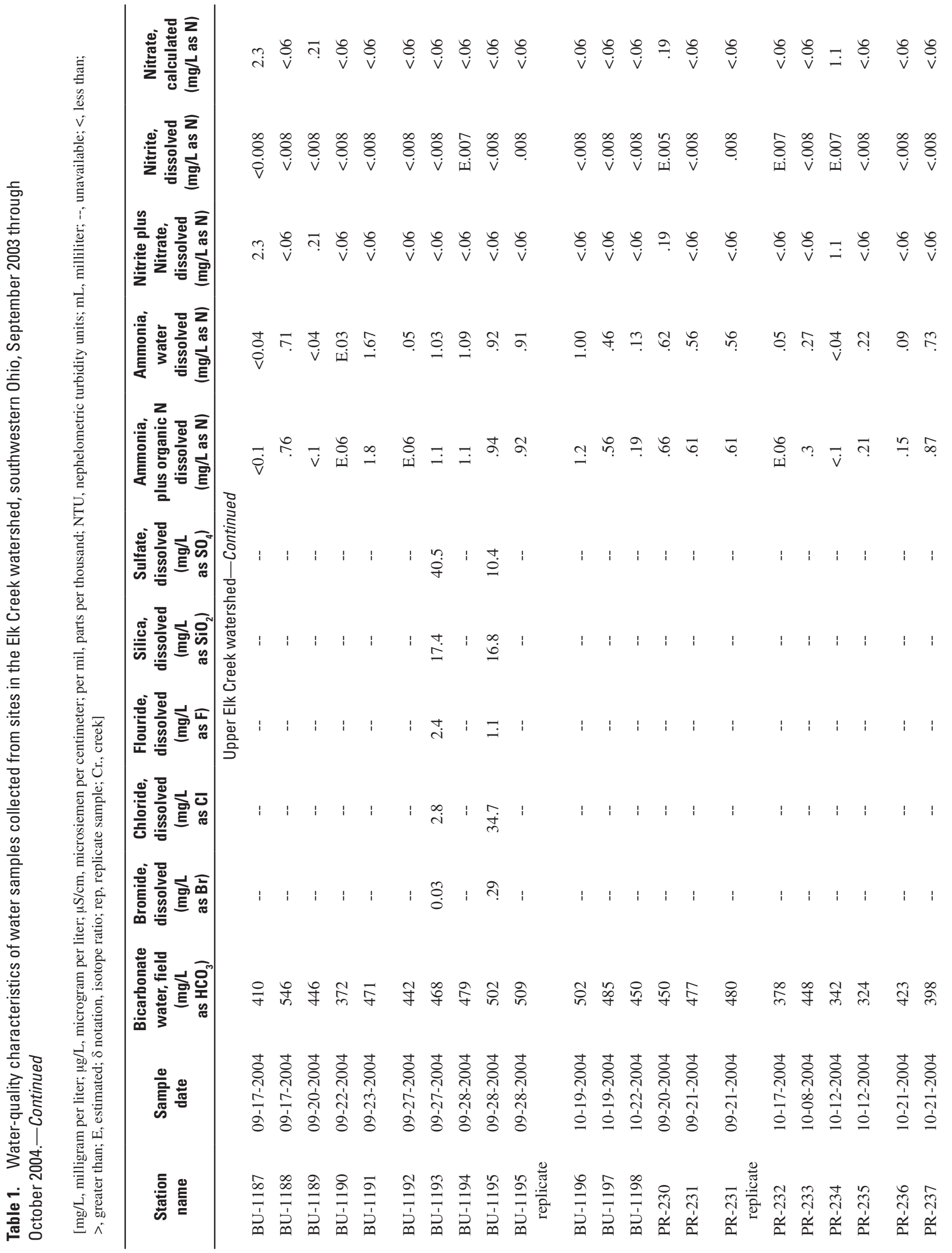




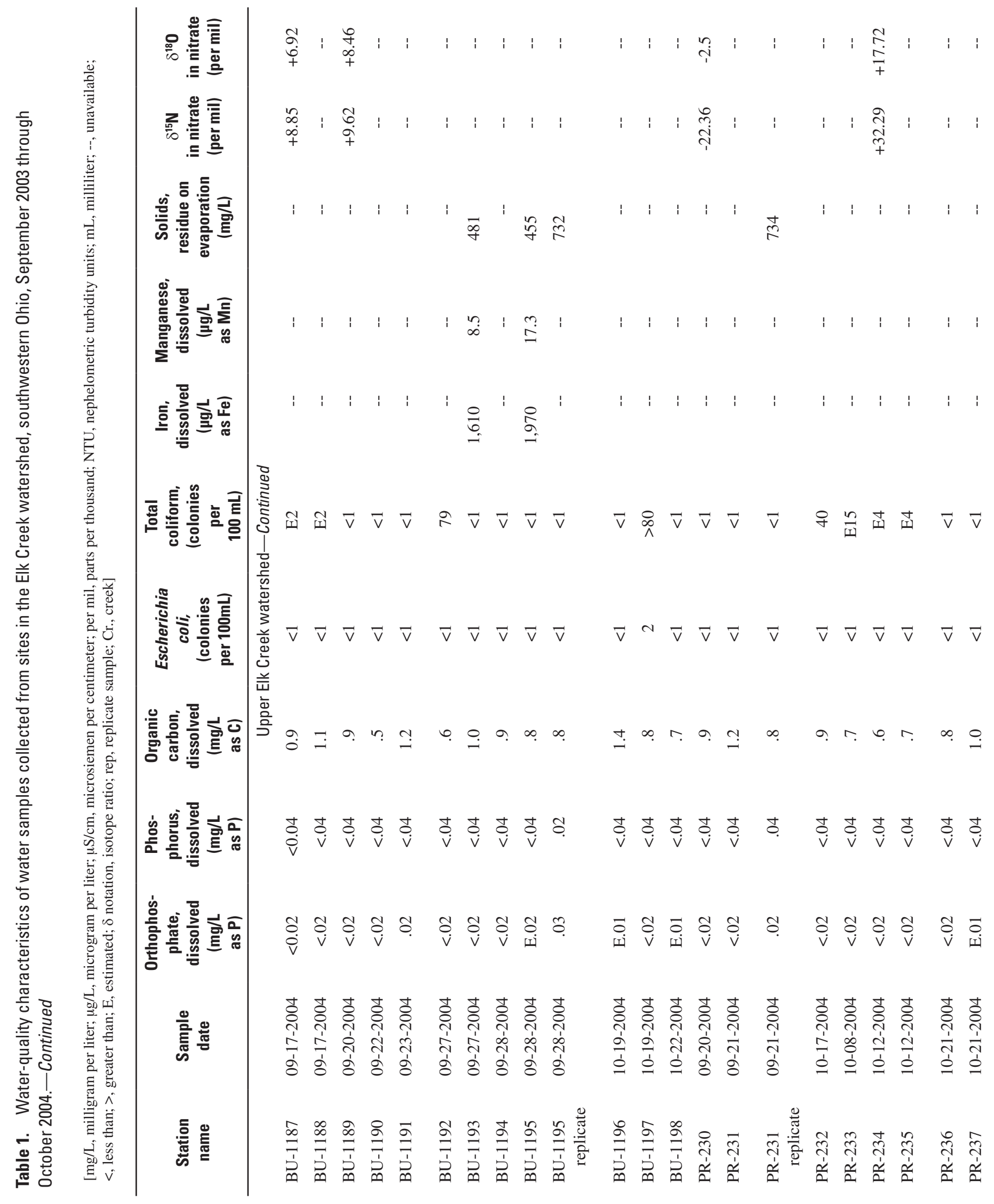




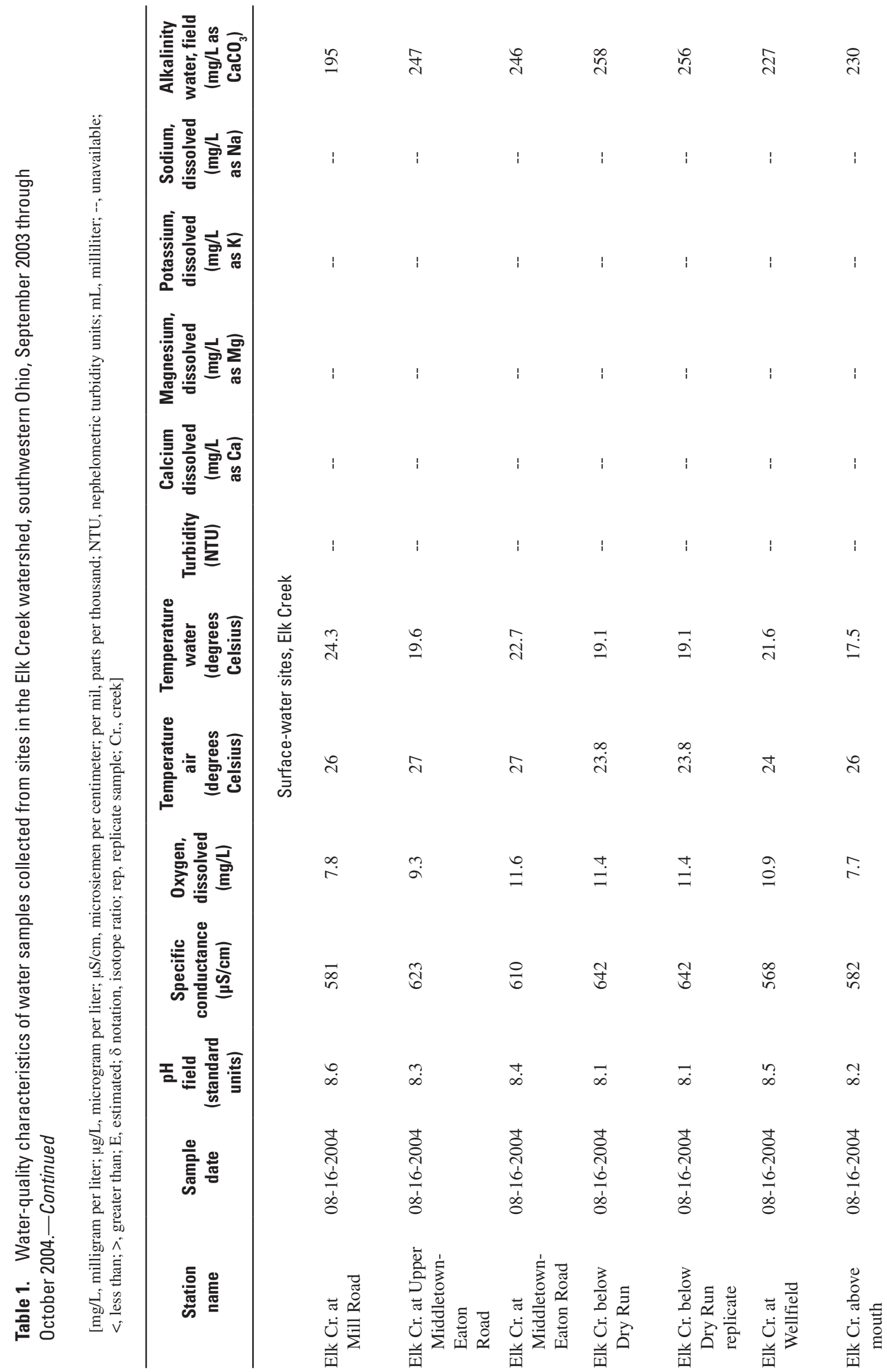




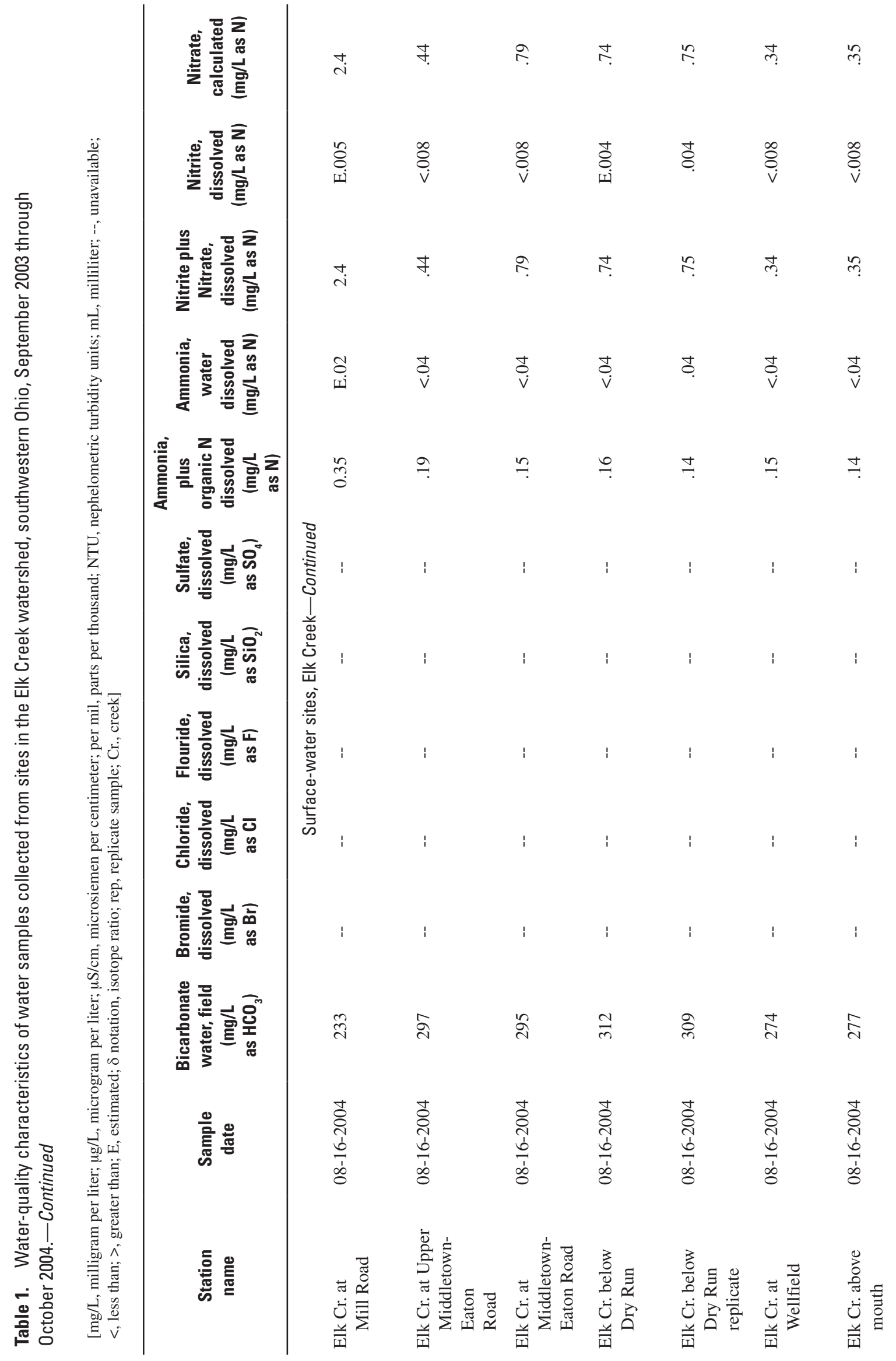




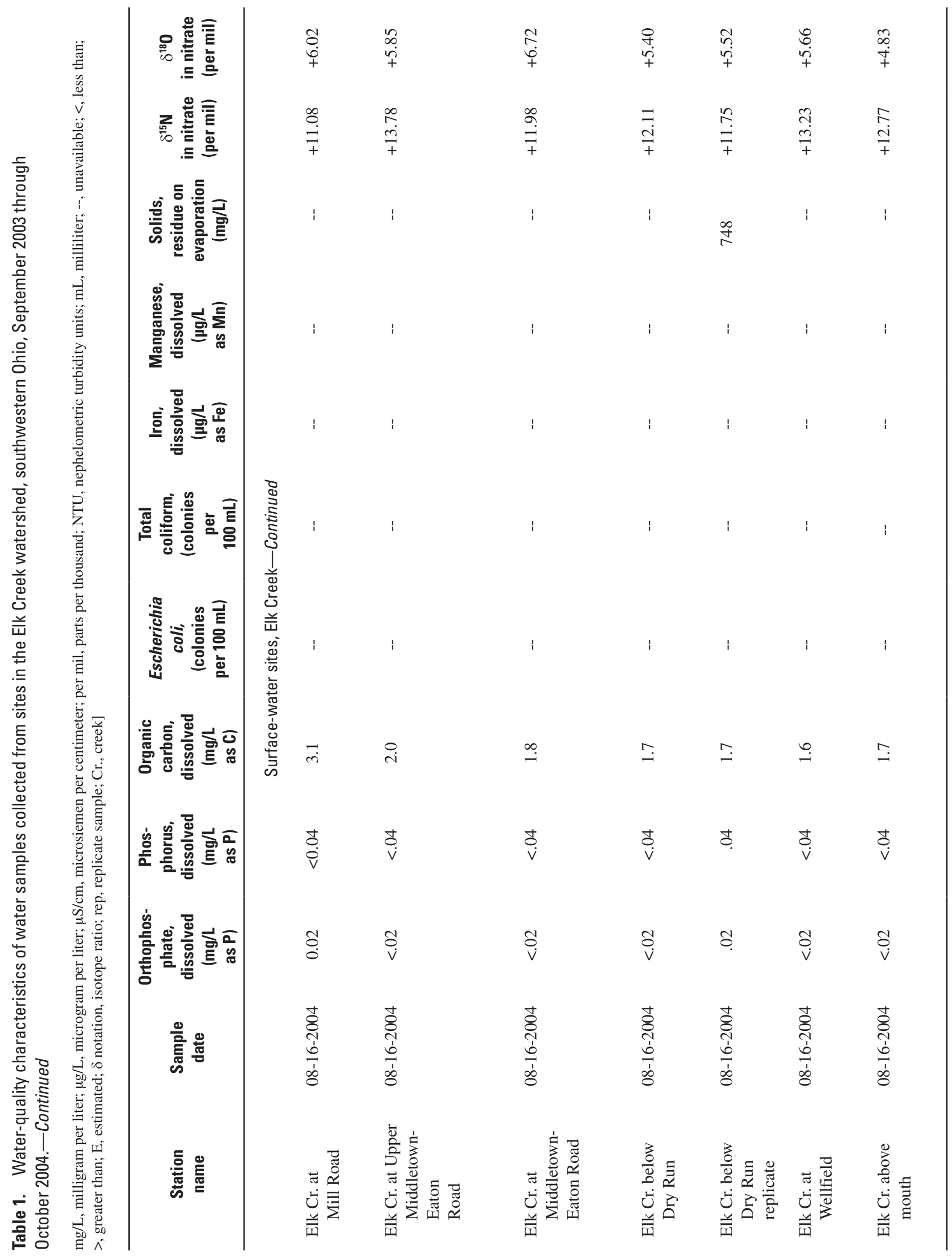


Table 2. Physical characteristics of wells sampled in the Elk Creek watershed, southwestern Ohio.

[ID, identification; --, unavailable; NGVD 29, National Geodetic Vertical Datum 1929; *, open end, no cap or screen; **, no casing; ?, uncertain]

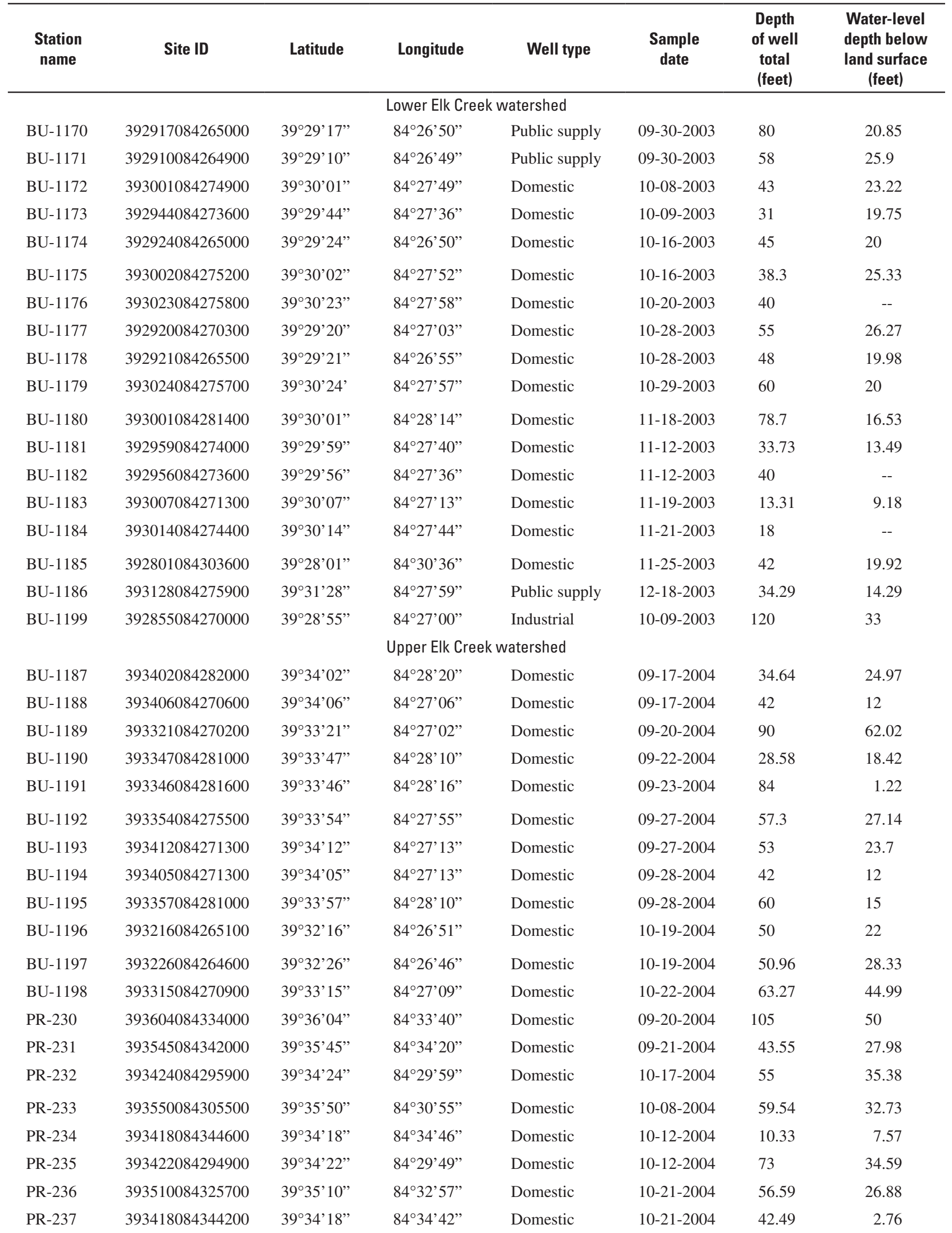


Table 2. Physical characteristics of wells sampled in the Elk Creek watershed, southwestern Ohio.-Continued

[ID, identification; --, unavailable; NGVD 29, National Geodetic Vertical Datum 1929; *, open end, no cap or screen; **, no casing; ?, uncertain]

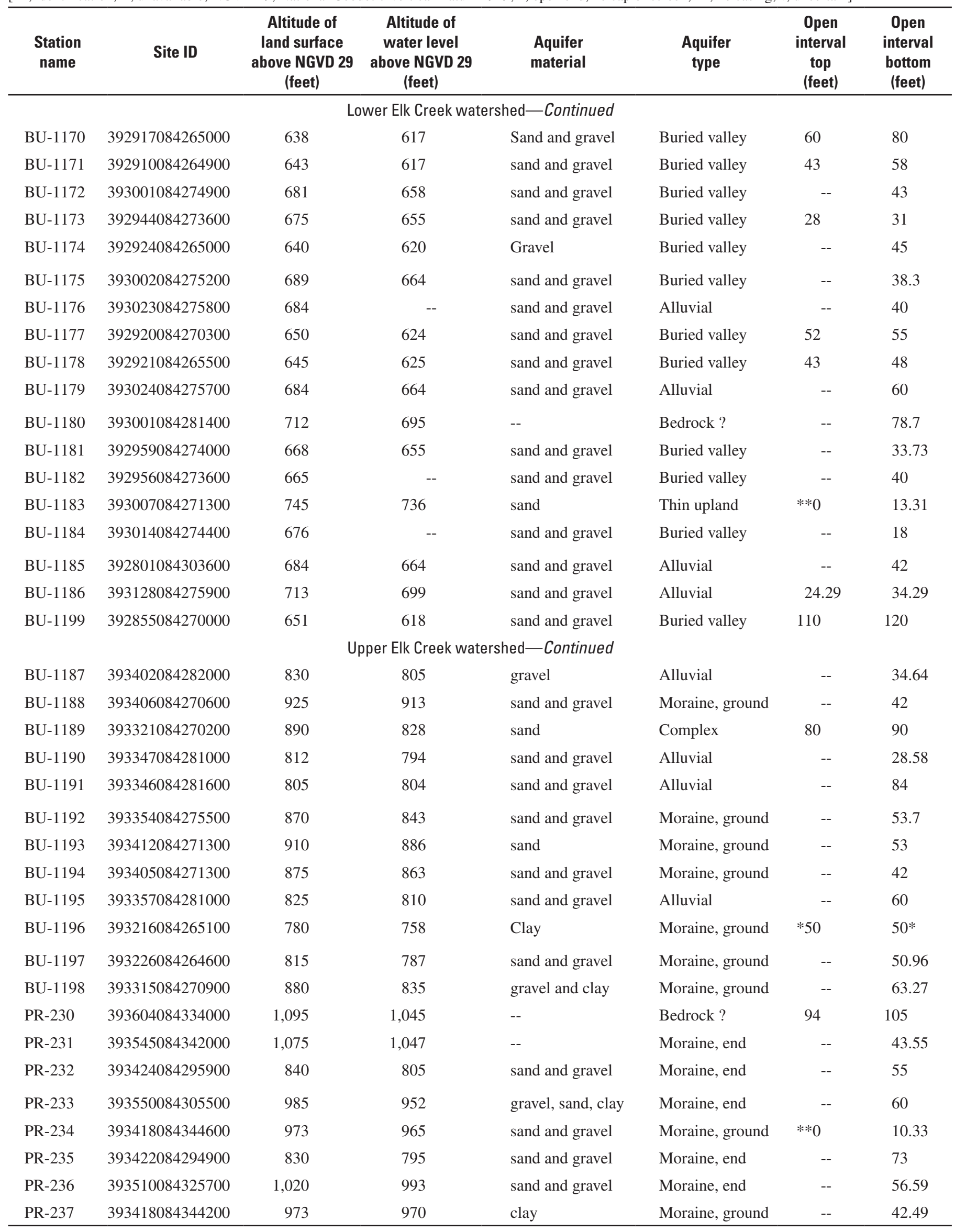


Table 3. Streamflow measurements at surface-water sites within the Elk Creek watershed, southwestern Ohio.

[ID, identification; $\mathrm{ft}^{3} / \mathrm{s}$, cubic foot per second; Cr., creek; Rd, road; ft, foot]

\begin{tabular}{|c|c|c|c|c|c|c|c|c|}
\hline Site ID & Station name & $\begin{array}{l}\text { Sample } \\
\text { date }\end{array}$ & Latitude & Longitude & $\begin{array}{c}\text { Altitude } \\
\text { (ft above } \\
\text { NGVD 29) }\end{array}$ & $\begin{array}{l}\text { Discharge } \\
\left(\mathrm{ft}^{3} / \mathrm{s}\right)\end{array}$ & $\begin{array}{c}\text { Gain/loss } \\
\quad\left(\mathrm{ft}^{3} / \mathrm{s}\right)\end{array}$ & $\begin{array}{c}\text { Discharge } \\
\text { error } \\
\left( \pm \mathrm{ft}^{3} / \mathrm{s}\right)\end{array}$ \\
\hline 393341084315200 & Elk Cr. at Mill Rd. & 08-16-2004 & $39^{\circ} 33^{\prime} 41^{\prime \prime}$ & $84^{\circ} 31^{\prime} 52^{\prime \prime}$ & 892 & 0.34 & -- & 0.03 \\
\hline 393215084274400 & $\begin{array}{l}\text { Elk Cr. at } \\
\text { Middletown-Eaton Rd. }\end{array}$ & 08-16-2004 & $39^{\circ} 32^{\prime} 15^{\prime \prime}$ & $84^{\circ} 27^{\prime} 44^{\prime \prime}$ & 729 & 1.51 & .79 & .08 \\
\hline 393137084280400 & Elk Cr. below Dry Run & 08-16-2004 & $39^{\circ} 31^{\prime} 37^{\prime \prime}$ & $84^{\circ} 28^{\prime} 04^{\prime \prime}$ & 705 & 1.74 & .23 & .14 \\
\hline Outfall & $\begin{array}{l}\text { Culvert on west bank of } \\
\text { Elk Cr. }\end{array}$ & 08-16-2004 & $39^{\circ} 31^{\prime} 01^{\prime \prime}$ & $84^{\circ} 27^{\prime} 58^{\prime \prime}$ & 690 & .014 & -- & -- \\
\hline 392926084264200 & Elk Cr. at Wellfield & 08-16-2004 & $39^{\circ} 29^{\prime} 26^{\prime \prime}$ & $84^{\circ} 26^{\prime} 42^{\prime \prime}$ & 625 & 1.95 & .21 & .10 \\
\hline 392921084262600 & Elk Cr. above Mouth & 08-16-2004 & $39^{\circ} 29^{\prime} 21^{\prime \prime}$ & $84^{\circ} 26^{\prime} 26^{\prime \prime}$ & 618 & .72 & -1.23 & .06 \\
\hline
\end{tabular}


This page intentionally blank. 


\section{蛋}

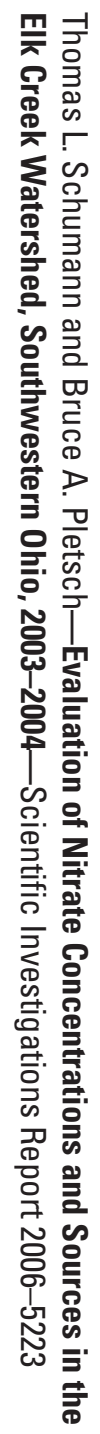

69 Printed on recycled paper 